\title{
ARTE, INTERCULTURALIDADE E RITUALIDADE: "PROYECTO DE DIFUSIÓN DEL PATRIMONIO EN VIDEO Y TV"
}

\author{
Maurício Camargo Panella ${ }^{1}$ \\ "O ser humano matou o animal que habita em seu interior." 2
}

George Bataille

Nosso processo de formação acadêmica, assim como nosso processo de formação como sujeito estão e são profundamente relacionados. O paradigma cartesiano que separou sujeito e objeto e que distanciou os saberes é refutado por nós como modelo de desenvolvimento de pesquisa. Nossas práticas vêm demonstrando que os saberes estão interligados. Nossas pesquisas junto aos departamentos de arquitetura, ecologia, artes e ciências sociais vem nos oferecendo ótimas possibilidades que configuram o paradigma holístico como mais propício para o entendimento dos papéis sociais humanos em relação com a totalidade da vida.

A experiência junto aos pesquisadores da complexidade como Edgar Morin nos aproximou da curiosidade e das pesquisas que são desenvolvidas em departamentos que abordam a vida por outra perspectiva. Nossos interesses principais sobre a poética do habitar humano, sobre os meios, as formas, as distintas compreensões de como as culturas habitam, compreendem, organizam e constroem seus espaços e seus tempos foram nos levando a re-conhecer e re-valorizar os saberes tradicionais, os saberes milenários que foram desconsiderados e muitas vezes destruídos a propósito.

Meu desafio como antropólogo foi sendo construído unido a meu desafio como artista, que foi sendo construído unido a meu desafio como educador. Entender a humanidade, as relações sociais, as relações entre o ser humano e a natureza e o cosmos, sempre foram minhas metas fundamentais. E são elas que dão a direção, o rumo, as rotas, as paisagens e os personagens que vou encontrando. O desafio de desenvolver um projeto artístico unido a pesquisa antropológica e a elaboração de métodos pedagógicos impõe uma sensibilidade que não se reduz a concretização de um objeto material belo e bem definido. $\mathrm{O}$ encontro com os saberes tradicionais necessariamente nos expõe a

\footnotetext{
${ }^{1}$ Universidade Federal do Rio Grande do Norte, Brasil.

${ }^{2}$ BATAILLE, George. El ojo pineal, Trad. Manuel Arranz, Valencia, Pre-textos, 1997.
} 
história da colonização do Brasil, do México e da América como um todo. Quando se trabalha e se desenvolve um projeto artístico que também tem uma função pedagógica e social imediatamente há que se trabalhar com as feridas históricas e psicológicas que as pessoas trazem devido aos problemas econômicos que se encontram em áreas como a do Nordeste brasileiro. O pedagogo Paulo Freire nos deixou muitas reflexões sobre o tema. Há que se olhar para o indivíduo como ele é, com o que ele traz; e conseguir ver sua sabedoria, sua força, seu conhecimento, sua experiência diante da realidade de onde ele está.

O distanciamento lógico e vivencial que se dá entre a realidade urbana e a realidade rural também é muito grande, o que nos torna como artista e antropólogo e também como educador, um tradutor que viabiliza e ergue pontes para que ambas as realidades possam ser tocadas e compreendidas sem preconceito. Bataille aposta que a humanidade tem que retomar as suas capacidades de comunhão integral com o mundo. O diálogo com o entorno, com o todo, é fundamental para poder compreender e perceber os personagens e as paisagens que irão oferecer as respostas às nossas dúvidas. Bataille revoga a antropologia científica por uma antropologia mitológica inserindo o ser humano/ pesquisador/ antropólogo/ cientista social diretamente ao objeto que ele estuda. A vida do próprio pesquisador se transforma numa aventura mítica. Não há separação entre objeto e sujeito. Eles são um dentro da construção das histórias de vida que se estabelecem pelo contato físico, onírico e social.

Bataille relaciona a animalidade humana ao movimento energético que a terra faz ao redor do sol. Sugere a realização de um sacrifício da racionalidade, um sacrifício do paradigma que concebe todas as relações somente sendo verídicas e importantes desde que partam de um grau de utilidade para os sujeitos envolvidos (Bataille, 1997: 57). As pesquisas junto aos elementos levam a retomar essa animalidade. As criações e investigações sobre o imaginário dos elementos naturais me levaram a entender como se diferencia a experiência na Terra guiada por uma vivência profana ou por uma experiência sagrada. Baitalle define muito bem aonde habita essa diferença. O Mundo Profano é aquele aonde tudo e toda a ação tem que ter uma utilidade. Já o Mundo Sagrado não interrompe a intimidade dos seres e o mundo. Sacrificar, destruir o profano é para o autor um caminho capaz de devolver a intimidade perdida. A intimidade com o mundo ata os seres humanos, as pessoas e as paisagens de onde está, descortinando a fragmentação e a separatividade entre os sujeitos e entre eles e o cosmos. O Cosmos 
gira, a Terra gira, os Humanos giram, toda a vida gira. Essa totalidade vivida é a retomada da intimidade do sujeito com o mundo.

Finalmente essa forma de encarar a vida abre um sentimento de imanência, de pertencimento ao movimento cósmico. A imanência no ser desperta sua integralidade enquanto indivíduo que pesquisa o mundo consciente de que ele está em seu interior. Ele comunga dos mesmos movimentos fundacionais que permitem que a terra e o cosmos girem. Isso abre o sentimento de continuidade com o meio. E é esse sentimento de continuidade, de pertencimento que funda nossa pesquisa antropológica como mitológica, como denomina Baitalle. Nos sentimos pertencendo aos Deuses e nos sentimos pertencendo aos mitos.

\section{Brasil, Espanha e México: a construção de uma linguagem crítica e sensível}

Em setembro do ano de 2005 realizo uma viagem à cidade de Granada para defender parte da tese de doutoramento na Facultad de Bellas Arte. Nesta mesma ocasião fui visitar a Biblioteca Municipal do Albaycín para ver os amigos que trabalhavam lá. Encontrei a diretora, que no ano 2001 havia recebido a primeira oficina de fotografia pinhole ${ }^{3}$ como meio para desenvolver o projeto de educação patrimonial no bairro desenvolvida pela Asociación Socio Cultural Mundurukum ${ }^{4}$, da qual eu era fundador. Em conversa ela me perguntou o que estava fazendo em Granada, e lhe comentei sobre a apresentação da investigação na Facultad de Bellas Artes e também sobre o documentário "Memórias de um pequeno parente do mar" 5 ; que também era uma aposta por um projeto artístico com uma finalidade educativa patrimonial. Foi então que a diretora me comentou de um projeto que havia sido realizado no bairro, também na área da educação patrimonial, coordenado por um professor alemão do Departamento de Antropologia da Universidad de Granada. Ela me deu o telefone do Professor Gunther Dietz e no dia seguinte eu liguei para ele. Agendamos um encontro.

\footnotetext{
${ }^{3}$ Fotografia Pinhole: uma câmara estenopeica ou câmara pinhole é uma máquina fotográfica sem lente. A designação tem por base o inglês, pin-hole, "buraco de alfinete" e é usada para referir a fotografia estenopeica. Este tipo de fotografia é uma prática econômica e simples, pois utiliza uma caixa qualquer em que a luz não penetre. A existência de um pequeno furo, estenopo do grego stenopo, é o que em português permite designar este tipo de fotografia por Fotografia Estenopeica.

${ }^{4}$ Asociación Socio Cultural Mundurukum: associação cultural fundada na cidade de Granada no ano de 2001.

${ }^{5}$ Memórias de um Pequeno Parente do Mar: documentário premiado pelo Festival Mada 2006. Direção Maurício Camargo Panella (50 min.)
} 
Em nosso primeiro encontro Gunther Dietz me perguntou o que eu vinha realizando no Brasil e se tinha algum material para mostrar para ele. Eu trazia o documentário "Memórias de um pequeno parente do mar". Mostro para ele e me pergunta se estava subtitulado. Digo que não. Então ele, neste mesmo primeiro dia de encontro, disponibilizou dos recursos econômicos que haviam sobrado do projeto do Albaycín para pagar os custos necessários para subtitular o filme. Em dezembro daquele ano iria ocorrer o Congresso Internacional de Antropologia na Universidad de Granada e o Professor Gunther então me convidou para lançar o vídeo no evento. O encontro com o Professor Gunther desde o início foi frutífero e confiante. Meses mais tarde esse encontro mostraria o longo e profundo caminho que se abriria.

Gunther havia me convidado para desenvolver um projeto junto às bibliotecas de Granada sobre memória e audiovisual. Fiquei em Granada aguardando por um tempo a resolução, mas finalmente tive que voltar ao Brasil. Acreditava que não mais trabalharia com o professor Dietz. No entanto um ano e meio depois de termo-nos conhecido em Granada eu abro uma conta de email já inativa e lá encontro um email do professor comunicando-me que já não trabalhava na UGR e que havia se transferido para o México, para assumir um posto de coordenação sobre os assuntos relacionados a Interculturalidade na Universidad Veracruzana, no estado de Veracruz. Respondo imediatamente seu email me colocando à disposição para desenvolver minhas propostas junto a ele, caso houvesse essa possibilidade. A resposta do professor foi um convite para desenvolver um projeto junto a Universidad Veracruzana Intercultural.

\section{Revolução, arte e Interculturalidade}

Nossos passos, quando sinceros sobre a Terra, por detrás deles, quando nos viramos para ver o caminho trilhado, vemos as flores e os frutos que brotaram devido a generosidade, a determinação e a consciência semeados por eles.

Eu já havia estado no México por duas vezes antes de aceitar essa missão de coordenar este novo projeto junto a Universidad Veracruzana Intercultural. Nos anos de 1995 e 1996 fui ao México por motivos pessoais. Nas duas ocasiões vivi encontros bem próximos as culturas originárias deste país. Na primeira estadia chegava ao México 
justamente na ocasião em que o Exército Zapatista de Libertação Nacional (EZLN) ${ }^{6}$, dirigido pelo Subcomandante $\operatorname{Marcos}^{7}$, realizava levantes contra o governo e as empresas que queriam explorar os bens naturais das terras do Chiapas. Numa viagem a San Cristoban de las Casas, em janeiro de 1995, era comum encontrar por toda a estrada tanques de guerra que paravam os veículos para fazer vistorias. Era um ambiente tenso que o país vivia, principalmente nas regiões mais ao sul do país.

No México, historicamente sempre houve levantes de grupos indígenas reclamando e exigindo o pertencimento e o cuidado das terras e o reconhecimento dos saberes dos povos originários. Juntamente com as lideranças indígenas, historicamente também os intelectuais e os representantes da cultura nacional se juntam para fortalecer a causa. Em 1994, no levante dirigido pelo EZLN, novamente o país se juntava e expressava pelas mídias internacionais o flagelo que os povos originários e a terra viviam. E foi em decorrência deste levante que se iniciaram as discussões que elaborariam anos mais tarde a formulação das Universidades Interculturais em distintas regiões na nação mexicana com a finalidade de fortalecer os agentes locais e os representantes das nações originárias.

A realidade cotidiana e a forma como são entendidas as relações sociais e com o meio natural são muito distintas entre as populações rurais e urbanas. De mesma forma, mas de modo menos acentuada, as realidades entre diferentes povos indígenas também divergem. O que faz com as políticas públicas elaboradas nacionalmente não possam ser as mesmas para toda a população. Assim, parte das exigências requeridas pela liderança da EZLN era do reconhecimento da diversidade cultural e que as políticas atendessem essas demandas. Uma delas era a criação das Universidades Interculturais para que os saberes e cursos oferecidos nas áreas interculturais fossem específicos para a realidade em questão.

Distintamente da realidade brasileira, que pouco reconhece o patrimônio indígena, no México, devido a sua própria formação cultural e histórica civilizacional distinta da do Brasil, sempre reagiu de forma mais contundente às opressões dos sistemas que batem de frente às cosmovisões dos povos originários. O ano de 1994 foi fatídico para a nação mexicana e eu estava lá no início de 1995 para ver com meus

\footnotetext{
${ }^{6}$ EZLN: Exército de Libertação Nacional- fez sua primeira aparição pública no dia $1^{\circ}$ de janeiro de1994 ao lançar uma ofensiva militar que tentou tomar sete cabeceiras municipais do estado do Chiapas, estado da região sul do México. Sua bandeira era: democracia, libertad, tierra, pan y justicia para los indígenas. ${ }^{7}$ Subcomandante Marcos: o 'Subcomandante Marcos', é o principal porta-voz do comando militar do grupo indígena mexicano chamado Exército Zapatista de Libertação Nacional (EZLN).
} 
olhos, ainda muitos jovens, a opressão, o medo e a revolta que o povo não deixava emudecer.

Ao mesmo tempo em que eu me aproximava e me sensibilizava com o movimento político zapatista também me aproximava fisicamente e espiritualmente com algumas das tantas culturas originárias. Essa aproximação ressignificava a minha compreensão sobre a América Latina, ressignificava a minha compreensão da experiência como humano sobre a Terra. As culturas mesoamericanas definitivamente desenvolveram pensamentos, tecnologias, hábitos, crenças e rituais que fortalecem até os dias de hoje uma relação mais estreita com a totalidade cósmica; tanto espacial como temporal. Adentrar na alma mesoamericana é adentrar também no tempo espacial e cósmico.

O mais incrível em toda a cosmovisão mesoamericana, tão complexa de elementos, símbolos, significados, formas e expressões, é que pela simplicidade de atos e hábitos cotidianos podemos adentrar nesse tempo sagrado. Claude Lévi-Strauss (1969) chamou isso de ciência do concreto. Em 1996 eu tive essa oportunidade de adentrar no espírito complexo e simples de uma das tradições mexicanas que dá corpo a cosmovisão mesoamericana: o cultivo do milho. Junto a Inocente, sua família e a cultura Raramuri que vivem na Serra Tarahumara no Estado do Chihuahua, eu viveria o cotidiano silencioso e cuidadoso com esta semente, base espiritual e alimentícia de grande parte da população mesoamericana. Aquela experiência junto a cultura Raramuri ficaria marcado em minha alma por muitos anos, o que me faz até os dias de hoje ter uma compreensão diferenciada a respeito do que significa para a humanidade a sua relação com a terra e com as funções espirituais que envolvem o conhecimento e as práticas de cultivo tradicional. Somente no ano de 2007, quando trabalhei em Veracruz foi que pude adentrar mais profundamente nesta cultura e que neste trabalho tratarei de relatar.

É esta experiência de unificação com o tempo cósmico que Bataille traz para sua antropologia mitológica reivindicando a urgência de resgatar a animalidade perdida, que aproxima a humanidade de uma experiência mais contínua, íntima, sagrada e em comunhão com a totalidade da vida.

Sempre fomos muito críticos aos centrismos operantes da racionalidade dominante, e nossas propostas sempre foram em direção ao reconhecimento e o diálogo com outras racionalidades no mundo. Pelo Programa de Doutorado de Filosofia da UGR, aonde cursei duas disciplinas optativas, eu havia conhecido algumas ideias de autores latino-americanos que abordam filosoficamente o tema da interculturalidade. $\mathrm{O}$ 
cubano Raúl Fornet-Betancourt ${ }^{8}$ é um desses expoentes filósofos que busca afastar-se das convenções locais, nacionais e internacionais que são impostas por uma cultura dominante. Para este autor a interculturalidade representa um avanço no que diz respeito ao multiculturalismo, no sentido que este se refere à presença em um mesmo lugar de culturas diversas, que não estão necessariamente ligadas entre si. $\mathrm{O}$ multiculturalismo pretende defender a liberdade e a igualdade entre as culturas, buscando conquistar o respeito e a tolerância. Daí a evolução que Fornet-Betancourt sugere de uma sociedade multicultural para uma intercultural, aonde deve ser realizada mediante o encontro e o diálogo entre eles (Fournet-Betancourt, 1994).

Por uma filosofia intercultural cria-se um posicionamento próprio a nível metodológico e filosófico, aonde não são cedidos privilégios a nenhum sistema conceitual ou tradicional, mais privilegia a cultura nativa. Dentro de uma comunicação, a interculturalidade aparece como caminho de pensamento e de vida por um duplo movimento: querer entender e ser entendido.

O filósofo cubano parte do princípio da originalidade da cultura e com ele da pluralidade cultural, concluindo que não temos que dominar, converter ou impor nosso modo de ser e de pensar a ninguém. Na verdade, não existe um ponto homogêneo para a submissão de todos, mesmo que esse fato tenha sido predominante por muito tempo. A interculturalidade busca tratar bem, conhecer e aumentar a auto-compreensão do outro dentro de um diálogo que não o obriga a negar ou admitir tudo o que lhe é proposto (Lima, 2014).

Outro autor latino-americano que também se detém em discutir e abordar o tema da filosofia latino-americana é o argentino Enrique Dussel ${ }^{9}$. Dentro de uma perspectiva da visão europeia fincada no período da colonização da América, “1492”, aponta como a ideologia eurocêntrica fixou e determinou concepções históricas daquele período como a invenção, o descobrimento, a conquista, a colonização, a conquista espiritual como parâmetros que enalteciam a superioridade europeia sobre as culturas por eles colonizadas. Este autor sugere que estas ideias devem ser revisadas, pois esta visão de dominação imperial não deixa lugar próprio para o encontro com a alteridade do Outro (Dussel, 1993).

\footnotetext{
${ }^{8}$ Raúl Fornet-Betancourt: é um filósofo cubano conhecido por seus estudos no campo da cultura e sobre tudo por sua proposta de um diálogo intercultural desde a Filosofía latino-americana.

${ }^{9}$ Enrique Dussel: é reconhecido internacionalmente por seu trabalho no campo da Ética, da Filosofía Política, e da Filosofía latinoamericana e em particular por ser um dos fundadores da Filosofía da libertação.
} 
Enrique Dussel assim como Fornet-Betancourt entende a interculturalidade como um meio para que as diferentes culturas possam estabelecer diálogos que não necessariamente partam pelos comuns formatos de argumentação pré-estabelecidos e reconhecidos pelo pensamento eurocêntrico. Ou seja, a interculturalidade na visão destes autores é um meio por onde o Outro se mostra e se apresenta como único e prédisposto ao encontro.

Estes autores lidos nos anos de 2001 e 2002 nas aulas de doutorado na Faculdade de Filosofia me acompanhariam por muito tempo. E reapareceriam em minhas práticas novamente no ano de 2007 com o convite estendido pelo Professor Dietz para coordenar um projeto na Universidad Veracruzana Intercultural.

Quando o Professor Gunther Dietz me apresentou ao Coordenador do Departamento de Comunicação da Universidad Veracruzana Intercultural (UVI), Raciel Martinez Damion por email, eu ainda não imaginava quais eram os laços que eu ainda trazia em minha memória com a cultura do milho. Mas toda compreensão, todo entendimento, chega a seu tempo, quando se tem determinação e firmeza no leme que nos dirige a realização daquilo que nosso ser vem realizar sobre a face da Terra.

Cada persona tiene su "señal", es decir, muestra em su inserción em la vida diaria, em la familia y la comunidade lo que es, los frutos que puede ofrecer. Conocer a una persona sin saber cómo es su corazón o cuál es su "señal", no significa, realmente, "conocerla", sino solamente tener información superficial sobre ella. Cosmovisión Nahuatl.

Aceitar o desafio de coordenar um projeto num país estrangeiro foi uma decisão imediata. Decidir ir para Veracruz trabalhar com as populações originárias mexicanas era um sonho. Por email, ainda quando eu estava no Brasil, eu definia meu contrato de trabalho junto ao coordenador do Departamento de Comunicação da UVI. Sem conhecer ainda o Estado de Veracruz, sem conhecer os profissionais desta Universidade eu aceitava a missão de desenvolver o Proyecto de Difusión Del Patrimonio en Video y TV nas 4 sedes desta Universidade junto a alunos indígenas representantes de 13 etnias. Minha vida pessoal junto a minha família no Brasil teria que se reorganizar. Minha vida espiritual também. 


\section{Cosmovisão mesoamericana: epistemologia indígena}

O termo Mesoamérica, proposto por Paul Kirchhoff ${ }^{10}$ em 1943, se refere a área cultural cujos limites espaciais se estenderam no momento da Conquista entre os muitos dos povos que habitavam grande parte do território mexicano e da América Central. Este conjunto de povos que habitam a diversidade de regiões geográficas da Mesoamérica compartilham uma história em comum e numerosas características culturais. Nesta área se desenvolveram uma grande complexidade cultural ao nível de civilização em termos de saberes astronômicos, matemáticos, arqueológicos, medicinais, artísticos e espirituais. Esta região foi habitada por diversos povos préhispânicos entre eles os Maias, Olmecas, Aztecas, Toltecas e Zapotecas.

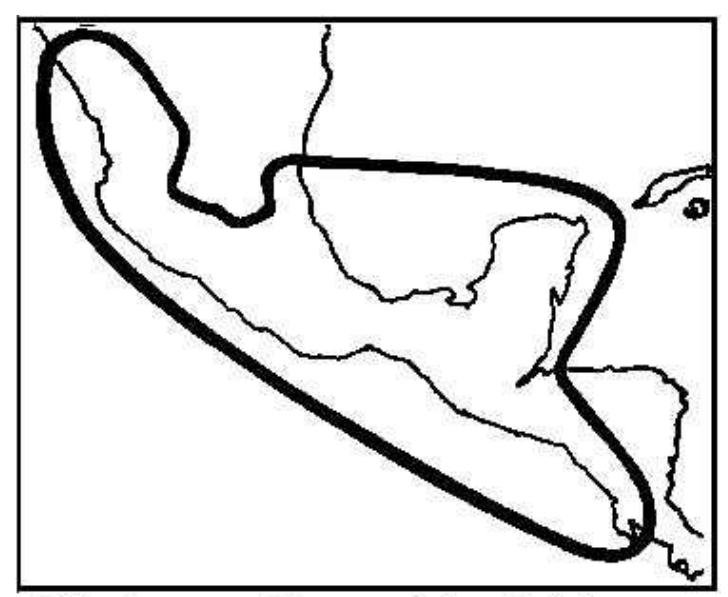

Límiłes de Mesoamérica a mediados del siglo XVI.

Adentrar no cotidiano das culturas indígenas do Estado de Veracruz significava adentrar no espírito que compõe a cosmovisão mesoamericana, significava adentrar na forma como as culturas indígenas organizam suas concepções de organização da vida material cotidiana atrelada a vida sagrada.

\footnotetext{
${ }^{10}$ Paul Kirchhoff: foi um filósofo e antropólogo alemão. Estudou na Universidade de Berlim, especializando-se em etnologia mexicana. Co-fundador da Escuela Nacional de Antropología e Historia, em 1938. Foi investigador da UNAM.
} 


\section{Comunidade e comunalidade na Mesoamérica}

As culturas indígenas entendem a realidade desde uma visão holística gerada a partir de um olhar multidimensional, no qual a fragmentação do saber acadêmico perde o sentido. A realidade é entendida pela sua totalidade cuja compreensão exige conhecer as partes. As relações que são estabelecidas com o núcleo familiar estão intrinsecamente relacionadas às atividades comunitárias e consequentemente vinculadas às transformações que o meio natural determina.

Esta perspectiva fica muito bem entendida quando se analisa o modo da estrutura da vida comunitária. Marcela Tovar Gomez ${ }^{11}$ adverte que a vida cotidiana dos integrantes de um povo indígena descansa sobre dois conceitos básicos: o da comunidade e o de comunalidade.

O primeiro se refere ao espaço comum. O segundo abarca a forma própria de organização e o sentido de pertencimento dos povos indígenas; os valores comunalistas de respeito mútuo, solidariedade, reciprocidade e democracia participativa, são os alicerces que dão embasamento ao sentido de comunalidade que fundamentam o diálogo intercultural.

A comunalidade pode então ser definida como mais que uma tendência ao relacionamento gregário. Ela pode ser vista como uma lógica que estrutura e articula a vida social. Por meio da comunalidade os povos indígenas expressam a vontade de fazer parte da comunidade, e fazer parte não somente por obrigação, mas sim por um sentimento de pertencimento, por sentir-se bem em fazer parte de uma mesma história, por sentir que compartilha de um mesmo espaço físico, uma mesma cosmovisão de cuidado de si, da família, dos animais, dos cultivos, dos rituais. Ou seja, o sentido de comunalidade propicia o sentimento de fazer parte de um coletivo.

Por esta concepção de mundo se entende que a realidade se organiza tendo como fundamento básico os princípios de funcionalidade e complementaridade de tudo o que abarca o cotidiano da comunidade. O sentido de complementaridade aparece assim como uma premissa que tem sua origem num entendimento de que todos devem respeito a todos. Este respeito tanto a nível pessoal, como comunitário e da mesma forma com o entorno natural. Seguindo este propósito tende-se a construir um ambiente com harmonia e equilíbrio.

\footnotetext{
${ }^{11}$ Marcela Tovar Gómez: professora da Universidade Pedagógica Nacional.
} 
A cosmovisão indígena está baseada por uma leitura e compreensão de mundo fundada e ancorada por uma visão multidimensional. A concepção do mundo por esta perspectiva abre a estruturação de um pensamento que considera a inter-relação existente entre outros mundos e outras dimensões de realidade, como por exemplo, o pensamento mágico-simbólico expresso por tantas formas metafóricas que podemos encontrar nas expressões artísticas mesoamericanas. Neste trabalho, quando nos debruçarmos nas atividades desenvolvidas em cada uma das sedes da UVI, trataremos de analisá-las.

Tik, tik, tik...

Carlos Lenkendorf ${ }^{12}$ seguramente é um acadêmico que se abriu ao universo intercultural e que vivenciou o espírito de comunalidade indígena por meio de suas pesquisas e trabalhos de campo junto a cultura maia. Como linguista e filósofo, e como humano sensível, Lenkendorf, pode escutar, sentir e perceber que o contato com o povo Tzeltal $^{13}$ somente poderia ser compreendido de modo profundo se ele se colocasse diante de uma nova forma de ler o mundo deixando para trás todo arsenal epistemológico eurocêntrico acumulado por anos; e assim então iniciar o processo de "enculturação", como ele mesmo denominou, para inserir-se em outra cultura sem préconceitos formulados e estabelecidos.

Ao iniciar seus trabalhos junto a cultura Tzeltala a convite de Samuel Ruiz García ${ }^{14}$, em uma de suas primeiras visitas as comunidades maias, impressionou-se com a repetição de uma palavra nos discursos:

\footnotetext{
${ }^{12}$ Carlos Lenkendorf: doutor em Filosofia pela Universidad Nacional Autónoma de México - UNAM, onde é titular e investigador de lingüística no Centro de Estudios Mayas. Dentre seus muitos livros se destacan: Diccionario tojolabal-español, español-tojolabal, Gramática del tojolabal, Los hombres verdaderos, Voces y testimonios tojolabales. En 1994 recebeu o Prêmio Anual Literário Hispanoamericano.

${ }^{13}$ Tzeltal: o grupo étnico mis numerosos que habitam Los Altos, região montanhosa localizada no Chiapas, México. É um dos muitos grupos que descendem dos mayas, conservando uma língua que pertence a rama deste grupo lingüístico e desta mesma cultura.

${ }^{14}$ Samuel Ruiz García: foi um religioso mexicano, prelado da Igreja Católica Romana, que serviu como bispo da Diocese de San Cristóbal de Las Casas, Chiapas, de 1959 até 2000. Foi defensor dos direitos dos povos indígenas de México e da América Latina.
} 


\begin{abstract}
Aunque no entendemos ni una sola expresión, escuchamos constantemente y con repetitiva insistência una sílaba o palabra que cada ponente o hablante usa y usa sin cesar. No se nos olvidanestos sonidos. He aqui están: lalalatik; - lalalatik, - lalalatik com la voz ascendente em la última sílaba. Nos preguntamos, ¿qué puede significar ese -tik, -tik, -tik? No lo sabemos y em el momento de 1 aasamblea no podemos preguntar a nadie. De todos modos debe ser algo de mucha importancia para los tzeltales reunidos. ¿Cuál será la razón de La reiteración? Debe Haber algún motivo de La repetición incesante (Lenkendorf, 2000: 161.).
\end{abstract}

Ao terminar a reunião Lenkendorf perguntou ao sacerdote que significava a palavra Tik, Tik, Tik. E o padre então explica que no idioma tzetal quer dizer NÓS e agrega ainda outra explicação adicional: o NÓS é um distintivo da língua tzetal e de todo o povo, e que NÓS é predominante não só na fala cotidiana, que se repete em muitas ocasiões na formulação das frases, mas que é uma atitude predominante na vida, na atuação e na maneira de ser do povo.

Carlos Lenkendorf ao adentrar na cosmovisão comunitária e comunalista maia junto ao povo Tzetal pode pela análise linguística conceber desde de dentro da cultura, como que o pensamento se originava e como este pensamento fundamentava a organização social deste povo. Sua experiência junto ao povo Tzetal ainda o fez perceber que esta mesma cultura lhe proporcionava ver que eles sim estavam dispostos ao diálogo, mas que ao mesmo tempo clamavam para que as pessoas externas à sua cosmovisão se permitissem adentrar em suas formas de entender, ler e viver o mundo.

Si nos quieren entender de verdad, si quieren captar la cultura nuestra, décimos La nuestra y no La mia ni de outro compañero u outra compañera, sino la nuestra, nuestra, tendrán que aprender el nosotros. Es un distintivo de nuestra cultura, de nuestra identidad, de nuestro modo de ser. Si de veras están interesados, escúchen nos; escuchen para inquietarse y para empezar a preguntar, a indagar, a averiguar. Tienen mucho que aprender. (Lenkendorf, 2000: 162.)

O linguista e filósofo, especialista em cultura maia, sugere que abríssemos um parêntese diante de tal reflexão, e que formulássemos a pergunta de qual seria a palavra ou sílaba ou o som de qualquer outro idioma indo-europeu que mais chamaria a atenção de um visitante de outra cultura. Ele acredita que somente estes visitantes estrangeiros é que poderiam nos responder à pergunta, estando certo que a resposta nos revelaria que nossos comportamentos podem nos parecer estranhos e questionáveis... 


\section{Agosto do ano 2007}

Contrato fechado com a Universidad Veracruzana Intercultural. Momento de organizar a vida familiar no Brasil para poder ir para o México e coordenar o Proyecto de Difusión Del Patrimonio em Video y T.V. no Estado de Veracruz.

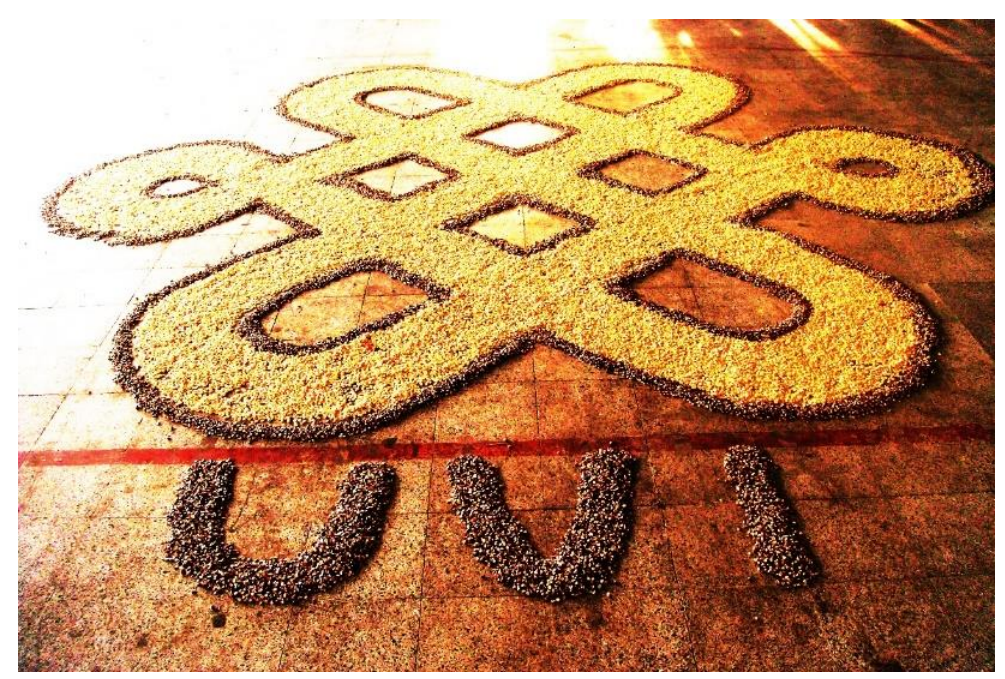

Universidad Veracruzana Intercultural - Uvi

A Universidad Veracruzana Intercultural promove o desenvolvimento de programas de ensino superior que contribuam para fortalecer as regiões interculturais do estado de Veracruz, ou seja, aquelas regiões que se reúnem por razões históricas grupos humanos pertencentes aos descendentes dos povos indígenas originários do Estado de Veracruz e também de outros povos indígenas de outros estados da república; assim como grupos e indivíduos vindos de outros países que também decidiram viver no mesmo território.

Entre seus objetivos também está a promoção de processos de geração de conhecimento dos povos das regiões interculturais através da formação de profissionais e intelectuais comprometidos com o desenvolvimento econômico e cultural na comunidade, regional e nacional, cujas atividades contribuam para a promoção de um processo de revalorização e revitalização das línguas e culturas indígenas tendo como fim formar profissionais que atendam às demandas da sociedade em suas regiões de 
origem e do Estado em programas acadêmicos gerais, transdisciplinares de uma perspectiva intercultural.

A Universidad Veracruzana Intercultural (UVI) nasce da ideia de criar uma universidade que atenda as comunidades que estiveram longe das oportunidades de ensino superior para os planos educacionais de acordo com o contexto das populações. Assim surgiu a Licenciatura em Gestão de Desenvolvimento Intercultural (LGID). Este grau é oferecido nas sedes regionais: Huasteca, Totonacapan, Grandes Montanhas e Selvas, sendo a sede central na cidade de Xalapa, conhecida como Casa UVI.

\section{Audiovisual como processo de pesquisa e como método pedagógico criativo em direção a educação patrimonial e intercultural}

Fui contratado para trabalhar nas 4 sedes da UVI com o objetivo de criar obras audiovisuais junto aos alunos do curso de Gestão em Desenvolvimento Intercultural que desenvolviam seus trabalhos focados na área da Comunicação. A aventura era tremenda, pois a UVI era uma recém criada Universidade como um braço da Universidad Veracruzana. Entrei para fazer parte de um grupo de profissionais que apenas iniciavam suas atividades nas sedes aonde a UVI atua. Nos anos em que trabalhei nesta Universidade nem sequer os campi estavam construídos e dávamos aula em centros sociais e espaços comunitários das comunidades que recebem os jovens de tantas outras localidades.

A Universidad Veracruazana Intercultural é um projeto audacioso e arrojado. Quando me lancei para trabalhar nas sedes da UVI não imaginava o que poderia encontrar, o que poderia viver. Mas a minha experiência anterior tão diversificada não me dava medo dos desafios que viriam. Quando fechei meu contrato, me haviam direcionado para ficar uma semana em cada sede dando o curso que me exigiam. Mas eu vinha de processos construtivos junto a comunidades que haviam tardado mais de ano. Eu sabia que o trabalho de construção criativa coletiva em comunidade não se abre da noite para o dia. Sempre soube que o trabalho em comunidade é um trabalho de escuta sensível, de contato sincero. É como uma flor que se desabrocha, pétala por pétala. Então sugeri a meu coordenador, Raciel Damion, que eu necessitaria permanecer um mês em cada sede. 
A diversidade cultural que se encontra nas sedes é muito grande. Há sedes aonde encontramos mais de uma etnia. Há sedes aonde os alunos falam mais de 4 línguas originárias, com suas 4 cosmovisões específicas. Cada sede está localizada em uma região do Estado de Veracruz. Cada região tem um ecossistema diferente do outro, um clima diferente.

Minha atuação nas sedes ocorreu em duas etapas distintas. Numa primeira eu itinerei por todas as sedes permanecendo um mês em cada uma delas. Iniciei em Setembro na Sede Totonacapan, em Outubro fui para a Huasteca, em novembro fui para Grandes Montanhas e em dezembro fui para Selvas. A cada lugar que eu passava, na sede seguinte já me aguardavam.

Eu estava trabalhando formando os jovens universitários da primeira geração desta Universidade. Todos nós, professores e alunos éramos “cobaias” de um projeto que ainda nos dias de hoje é, mesmo 10 anos passados, um recém-nascido dando os primeiros passos. Havia muita coisa ainda para aprender, para descobrir no caminhar do projeto UVI. Eu me senti muito agraciado por pertencer àquela família. Eu vinha de outro país, estava contratado e tinha à minha disposição profissionais e equipamentos. Era realmente uma situação ímpar para um antropólogo artista.

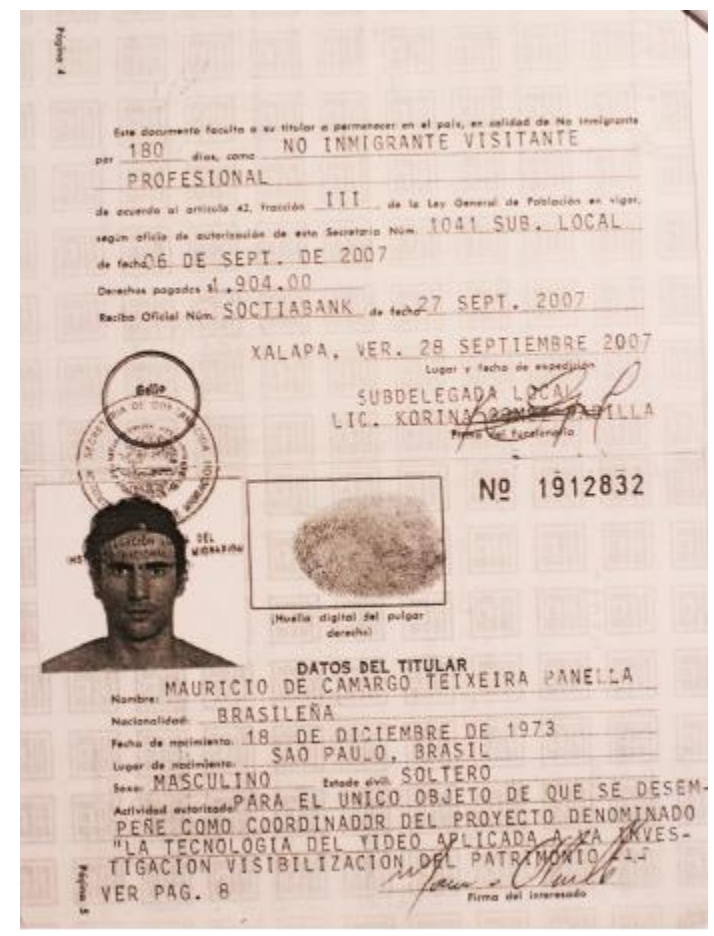

Meu documento/contrato de trabalho expedido pelas autoridades mexicanas. 


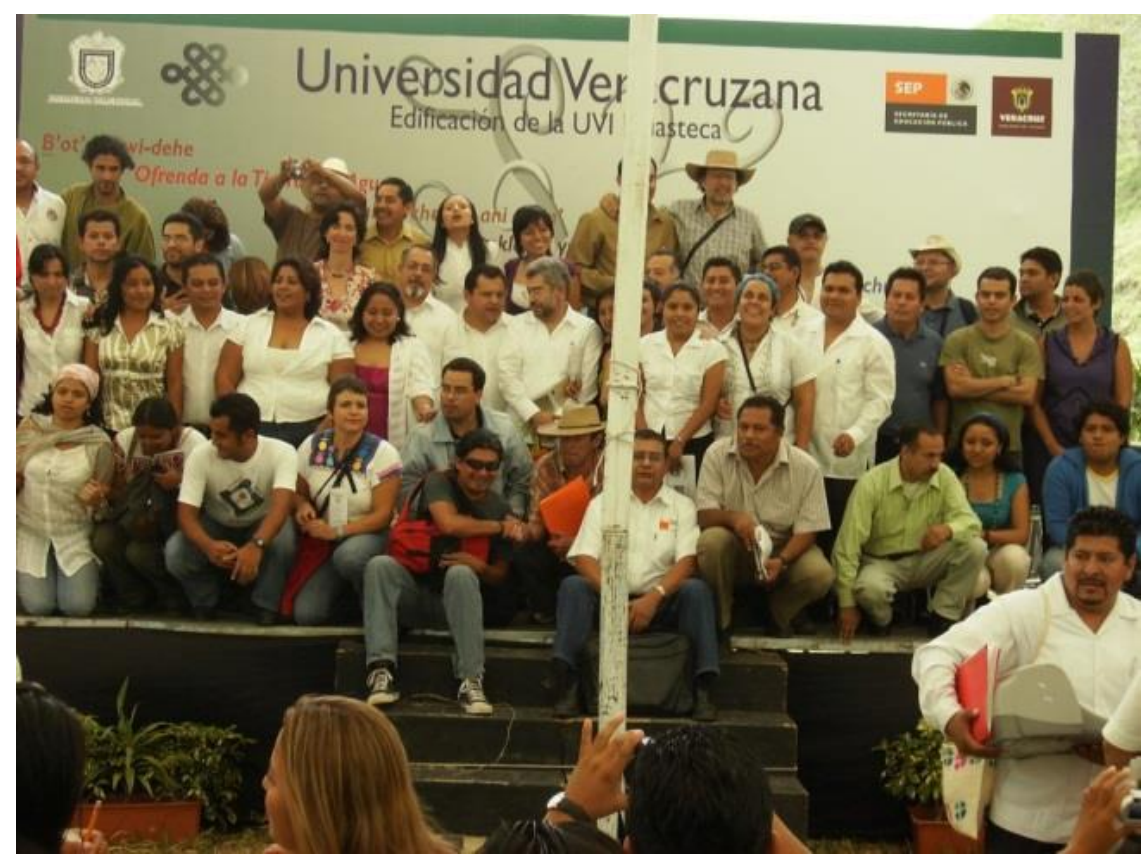

Evento da UVI na Sede Huasteca.

\section{Arte, ritualidade e comunicação dos sentidos}

De volta ao México. Depois de 11 anos regressava a este país para coordenar o Proyecto de Difusión Del Patrimonioen vídeo y TV junto a UVI. Cheguei em Xalapa na madrugada, Raciel Damion me havia dito que quando chegasse eu ligasse para ele. Liguei desde a Rodoviária. Era dia de eleição em Veracruz e ele como jornalista havia trabalhado todo o dia e a noite também. Disse-me que eu pegasse um taxi e que fosse para um hotel no centro da Cidade. Chego ao Hotel, instalo-me e descanso. Ainda antes do amanhecer, Raciel chega ao Hotel para me conhecer. Apareço na escada e desço. Ele me olha de cima a baixo e me pergunta: - Eres Maurício Camargo? E eu digo: - Si, Soy Yo. Muchogusto. Havíamos fechado o contrato por email, nunca nos havíamos visto, aquele era nosso primeiro encontro.

Naquela mesma madrugada Raciel me leva até a Casa UVI e me apresenta uma lista com a equipe de profissionais que trabalhava em Xalapa, e juntos reelaboramos o cronograma de atividades que eu executaria por todas as sedes da UVI. Eu apenas estava chegando. Aquela situação me deixava claro que havia um sentimento forte que pulsava naquele lugar. Afinal, quem iria para a sede de uma Universidade numa madrugada em dia de eleição? No dia seguinte pela manhã volto a Casa UVI e então sou apresentado a equipe e a coordenação. O Projeto UVI em 2007 era muito recente, todos 
os que ali trabalhavam se sentiam fazendo parte de um grande sonho de poder atuar pela educação intercultural e indígena mexicana. Havia um ar de educação revolucionária, uma vontade de conhecer as profundezas das culturas locais, e de poder marcar a história com o trabalho realizado. A UVI era e ainda é a única Universidade Intercultural mexicana apoiada totalmente com recursos públicos e com vínculo direto a uma Universidade Autônoma, a Universidad Veracruzana. E eu, brasileiro, estava ali sendo chamado para fazer parte deste projeto.

Desde o início sabia que ali havia muito mais que uma realização profissional. Todos os sinais que antecederam minha contratação já me haviam demonstrado que o envolvimento era também profundamente espiritual e emocional com aquelas pessoas, com aquela cultura e com aquele lugar. Eu vivia aquele momento realmente como uma epifania. Sentia-me preparado para os desafios que se apresentassem, mesmo ainda sem saber quais seriam.

Das outras vezes que eu havia visitado o México eu não havia passado pelo Estado de Veracruz, assim, não conhecia nada. Tudo era novo. Era preciso então abrir este novo, recebê-lo e saber compreendê-lo com entusiasmo, mas também com cautela. Seguramente a minha empolgação se sobrepôs sobre a responsabilidade que eu tinha sobre mim. Eram 13 culturas distintas, eram regiões afastadas umas das outras, climas distintos, geografias também distintas. Além disso, recaiam sobre mim a saudade e a preocupação com a minha família que havia ficado no Brasil.

O México é um país em que nos deslumbramos com a beleza, com a simpatia e com bondade das pessoas, mas também é um país onde a malícia, o jogo de interesses políticos, a magia e a bruxaria repousam. E Veracruz é decididamente um Estado aonde estes jogos de poder são frequentes. A situação atual que os habitantes deste estado vivenciam é um reflexo da imprudência que os líderes políticos exercem entre eles e para a população.

O período que eu tinha para desenvolver o projeto era muito curto, apesar de eu ter estendido a minha permanência de uma semana para um mês em cada uma das sedes. Mas mesmo assim, minha meta de ajudar aos alunos da primeira geração desta Universidad a transformar suas pesquisas em projetos audiovisuais, era um desafio muito grande. A metodologia que empreendi foi sendo construída, vivida e experimentada sede a sede. A base de nosso trabalho sempre esteve fincada nos princípios freirianos de investigação e participação coletiva. Isto sempre se manteve como base fundamental para todas as sedes. Em todas elas iniciamos nosso trabalho 
ouvindo os temas que cada um dos alunos tinha como objetivo de pesquisa. Na UVI, cada aluno ao iniciar suas atividades acadêmicas determina um tema relacionado a alguma questão que envolva a sua comunidade e, assim, cada aluno pesquisa, sob a orientação de um tutor, que orienta o trabalho até a sua formação final.

Os temas de meus alunos que seguiam a orientação de Comunicação dentro da UVI eram muito vastos. Grande parte dos temas escolhidos tinha relação direta com a identidade local. Ritualidade era um tema muito comum, as vezes aparecendo como um tabu. Eram muito presentes entre os alunos também recolher os mitos, as histórias tradicionais junto a seus pais, avós, parentes e anciãos das comunidades. Também muito comum eram os temas diretamente vinculados à saúde coletiva. Ainda nos pueblos veracruzanos é muito comum as várias formas de curandeirismo, que estão baseadas na utilização de plantas medicinais e práticas xamânicas. Outra prática muito comum é a função que as parteiras exercem nas comunidades. Ou seja, temas vinculados a medicina tradicional que erak trazidos para serem investigados e conhecidos grupalmente. Também comum eram os temas relacionados à cultura, tanto à produção cultural, quanto à reprodução da cultura, fosse pela forma de artesanato (têxtil, cerâmica, pintura, escultura, etc.), fosse pela expressão da dança e da música. A arte é desde os tempos pré-colombianos uma expressão apreciada e valorizada pelas várias culturas indígenas mexicanas. Em uma de nossas conversas com um Tlamatine $^{15}$ na região da Huasteca veracruzana, Don Atalo Cruz Reina ${ }^{16}$, que auxiliou muitas vezes os professores e alunos desta sede em suas pesquisas, se referia ao indígena sempre como um grande artista que entende os ciclos da natureza e que expressa esse entendimento pelas diferentes expressões artísticas.

Também outros temas que eram comuns entre as pesquisas dos alunos nas 4 sedes da UVI, eram as questões relacionadas ao meio ambiente, a poluição dos rios e dos bosques. Da mesma forma eram os temas relacionados à violência familiar. Fosse um tema ou outro que os alunos abordassem, sempre os temas estavam diretamente vinculados ao dia a dia deles, ao cotidiano de suas comunidades, às experiências de suas famílias, tanto quando o tema partia de uma família onde eram comuns as práticas ritualísticas e artísticas, quanto quando os temas partiam da convivência com as

\footnotetext{
${ }^{15}$ Tlamatine, em náhuatl: Tlamatini, os que sabem algo ou os que sabem coisas. São os homens sábios, equivalente aos filósofos na época dos mexicas. Também conhecidos como poetas, que debatem temas sobre a existência, a verdade, a natureza do cosmos e sobre o lugar do homem nele. Contribuiam na época antiga para o desenvolvimento dos aspectos filosóficos ligados a religião e eram professores nos Calmécac, escola dos sacerdotes e nobres.

${ }^{16}$ Don Atalo Cruz Reina: Tlamatine nahuatl que vive no município de Ixhuatlán del Madero.
} 
dificuldades econômicas e sociais que os alunos mesmos encontravam e viviam em suas casas. O que tornava o trabalho mais difícil e complexo. Ao mesmo tempo que o tornava mais desafiante, pois tínhamos em mãos a possibilidade de trabalhar criativamente alguns traumas seculares, traumas familiares, geracionais e ambientais.

Claro que estávamos lá por uma questão fundamental: formar os alunos para que pudessem utilizar as ferramentas audiovisuais em suas pesquisas, mas ao mesmo tempo estávamos lá ouvindo suas próprias histórias, pensando coletivamente sobre elas, expondo elas.

Minhas práticas anteriores junto às comunidades litorâneas do Brasil, aos ciganos da Andalucia, aos imigrantes do norte da África e também nos Centros de Juventude nas periferias do Brasil, já me haviam dado experiência sobre essa responsabilidade. E creio que sem saber fui me transformando num profissional que assumiu como meta de vida mesmo "Hacer sábio los rostros y firmes los corazones",17 das outras pessoas.

Nossas rodas de conversas eram sempre muito longas. Ao mesmo tempo em que eu queria ouvir as histórias dos alunos, eles também se interessavam em saber a minha história, afinal de contas para eles também não era cotidiana a presença de um brasileiro. O que nos punha numa situação bastante intercultural. Todos abertos para dialogar com o novo. Quando aceitei o convite de trabalhar nas sedes comentei para meu coordenador, Raciel Damion, que por experiência, achava mais adequado que eu ficasse o mais próximo da realidade dos alunos. Ou seja, eu não queria ficar hospedado em hotéis ou pousadas que me colocasse numa situação desigual socialmente falando. Eu já era o professor, já era brasileiro... E, se acaso eu ficasse num alojamento muito diferente do que os alunos estavam, seguramente nossa relação seria também marcada por essa diferença.

Assim, uma das exigências era que eu ficasse alojado nas proximidades das sedes e de preferência convivendo com aos alunos e outros professores da UVI. Essa minha decisão seguramente me abriu a um convívio mais direto e igualitário. Ao

\footnotetext{
${ }^{17}$ Hacer sábio los rostros y firmes los corazones. É uma das características que recai sobre a figura dos Tamatines dentro da cultura Nahuatl mexicana. As funções que um Tlamatini assume são: temachtiani ou professor, de ser o caminho e de servir como um guia para os outros. É cuidadoso como um médico e protege a tradição. É transmissor de sabedoria. Segue e a ensina. Ensina a verdade. É um Mestre da verdade. Ocupa o papel de teixcuitiani ou psicólogo: faz tornar sábio os rostos dos outros, ajuda aos outros a tomar uma cara, ajuda a desenvolver uma personalidade. Abre-lhes os ouvidos, lhes ilumina. É também um teyacayani ou pedagogo. Põe um espelho diante dos outros, os faz cuidadosos. É um netlacanecoviani, ou aquele que humaniza os desejos o querer das pessoas.
} 
mesmo tempo que, essa situação, fazia com que minha estadia estivesse, o tempo todo, envolta as questões comunitárias e psicológicas. Era uma faca de dois gumes: aproximou-me da realidade local e ornei-me amigo de todos, o que proporcionou uma interação e um contato muito mais profundo e intenso com a cultura local. Mas ao mesmo tempo, expôs-me, em demasia aos problemas comunitários.

Após conhecer os temas dos alunos iniciávamos as práticas para conhecer e saber manusear os equipamentos de vídeo e de áudio que a UVI tinha em cada sede. No entanto, havia poucos equipamentos para tantos alunos, o que nos obrigava a nos dividirmos em grupos e assim definirmos como executarmos nossas metas de modo que todos participassem do processo. Em cada uma das sedes inventamos um processo diferente, mas sempre nos fixando em um princípio geral, que aproveitaríamos as festividades, ritos, problemas e situações atuais que naquele momento estavam por ocorrer.

Neste relato narrarei as experiências e processos de criação e pesquisa que foram desenvolvidos em uma das Sedes: a Huasteca.

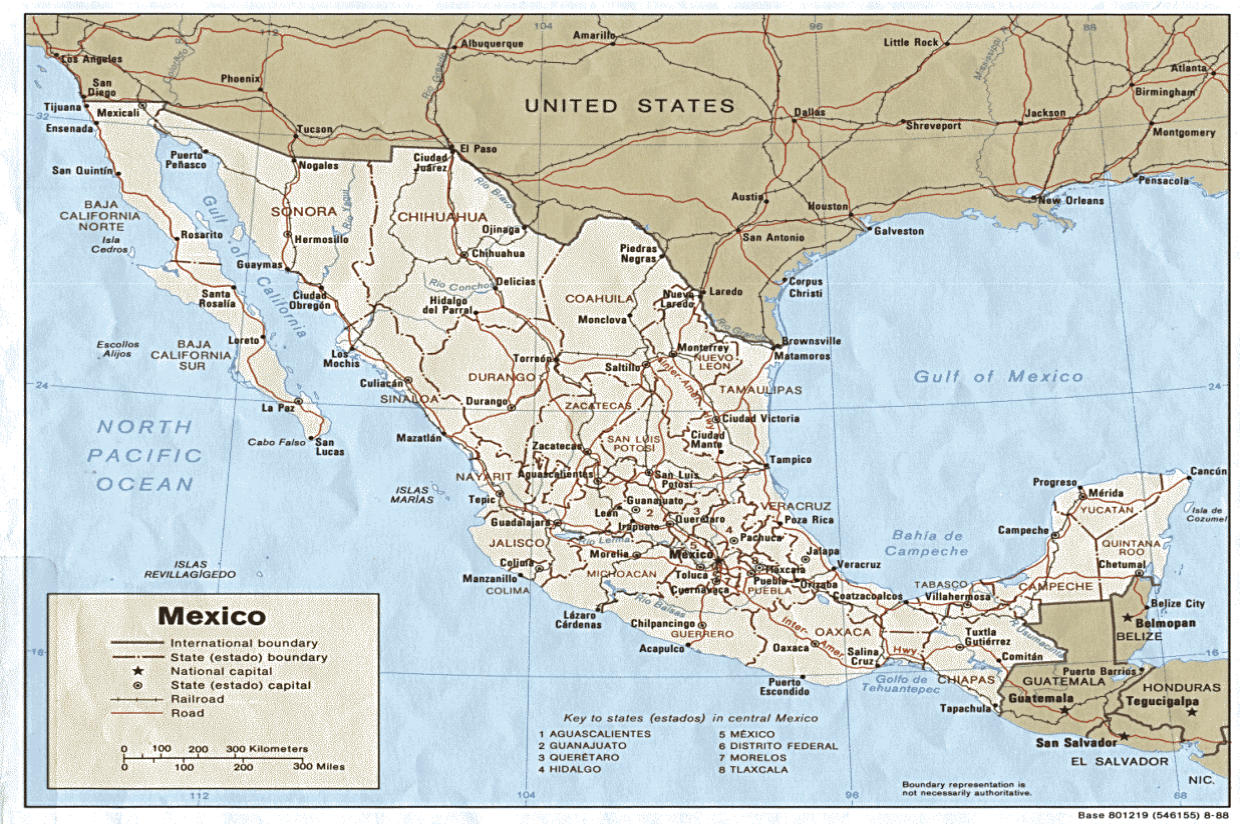

Mapa da República Mexicana. 


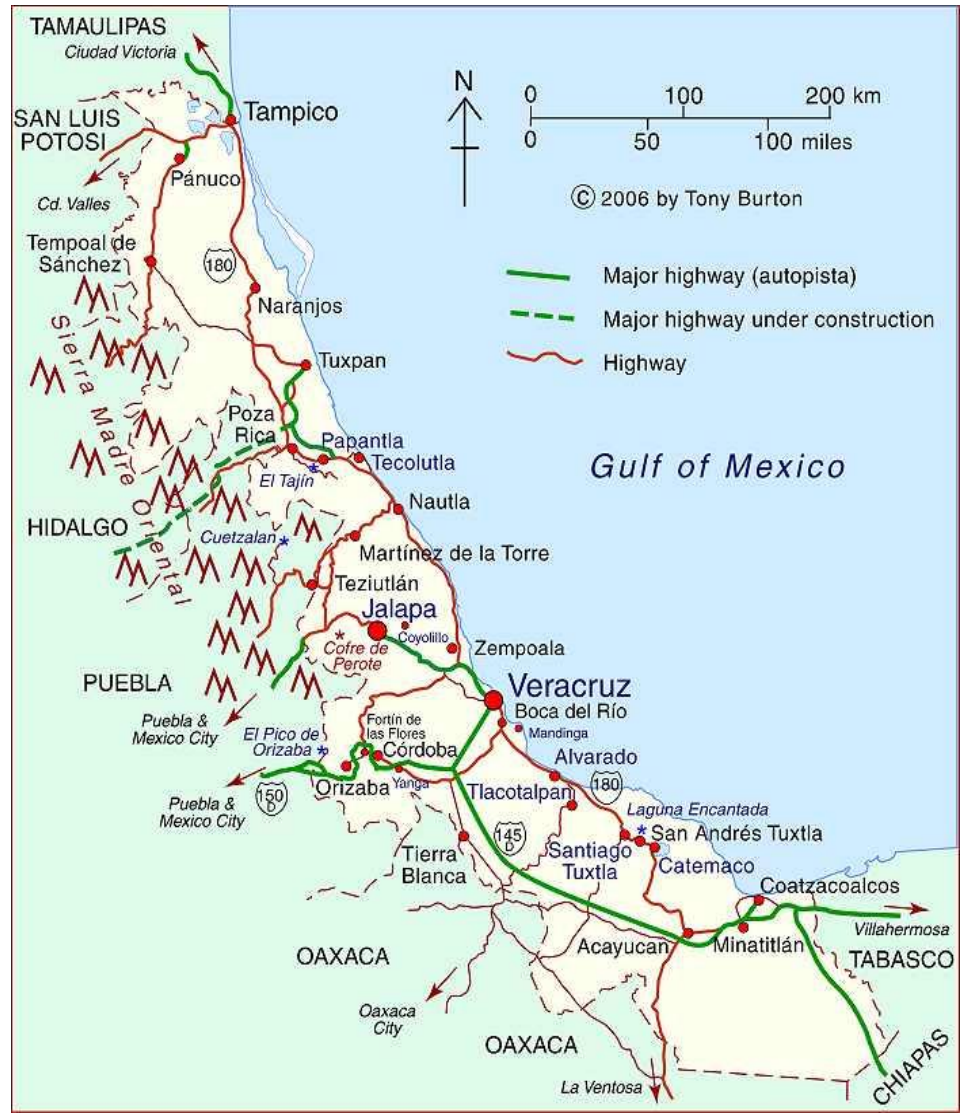

Mapa do Estado de Veracruz - México

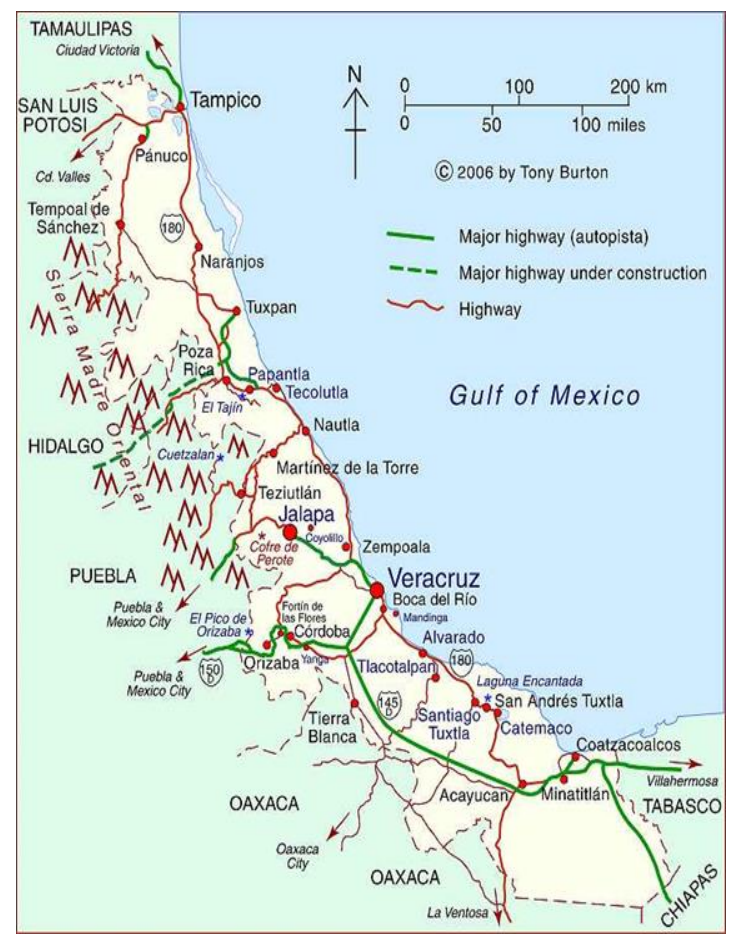



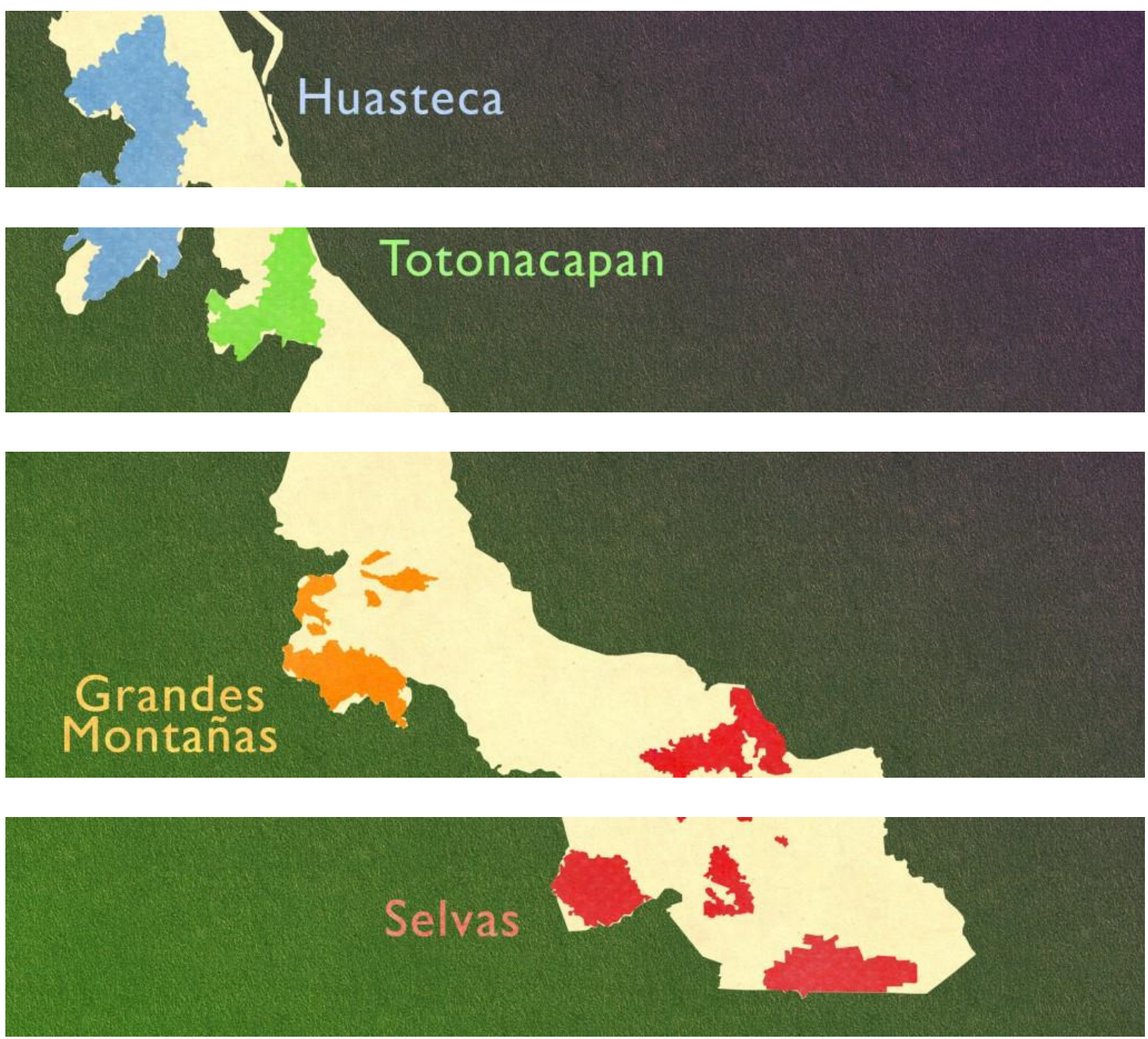

Representação das áreas que as sedes da UVI atendem nas regiões interculturais. 

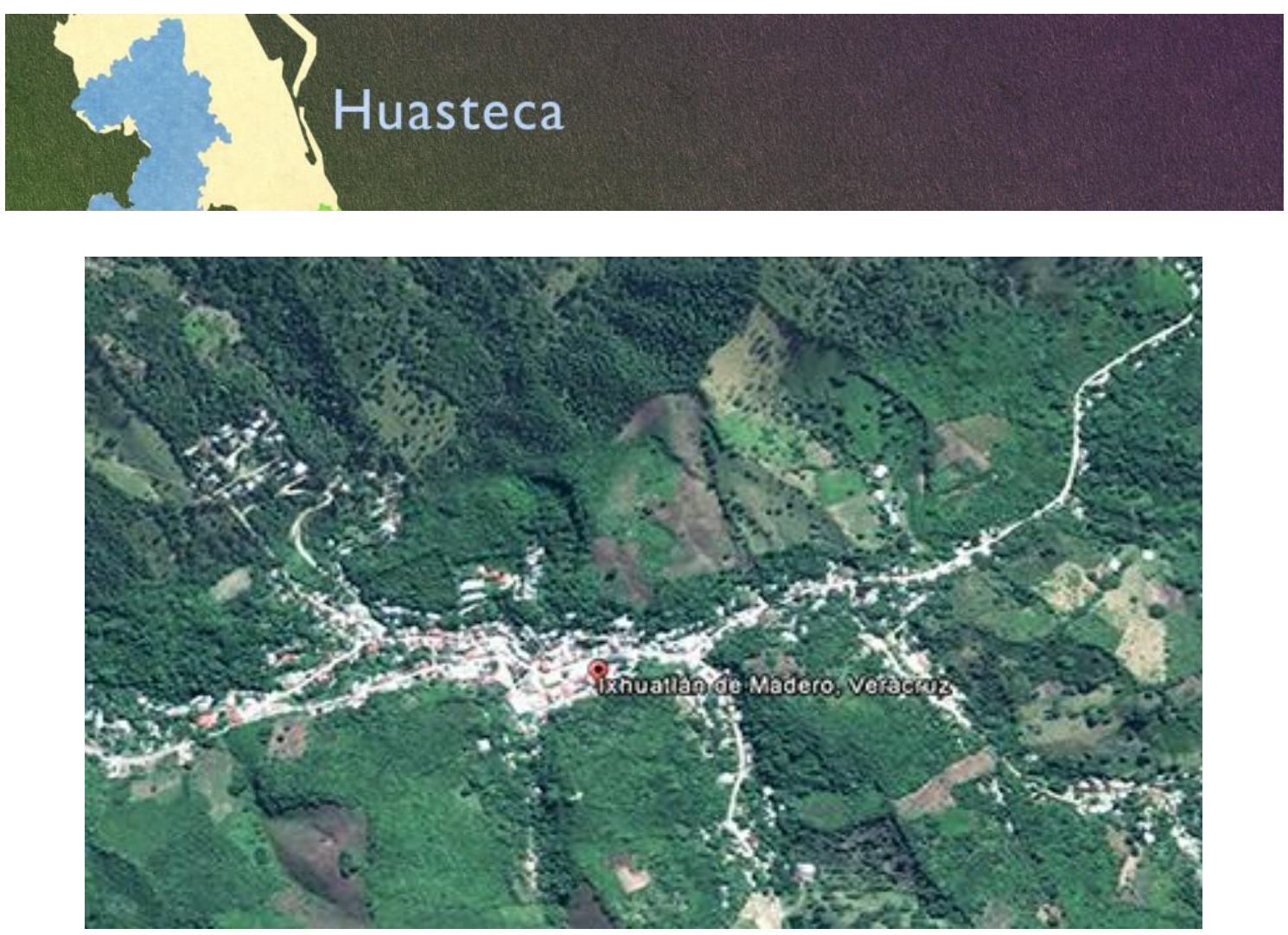

Huasteca: sede que recebe os municípios de Ixcatepec, Chontla, Citlaltépetl, Tepetzintla, Ixhuatlán de Madero, Tlachichilco, Zacualpan, Texcapetec, Zontecomatlán, Ilamatlán, Benito Juárez, Chicontepec, Chalma, Chiconamel, Platón Sánchez, Tantoyuca e outros municípios veracruzanos e de estados vizinhos dentro da Região Intercultural Huasteca.

Chegar a Huasteca é por si só um grande desafio. A imagem aérea demonstra que Ixhuatlán de Madero, município que recebe a sede da UVI, está fincada entre bosques e serras. Meu coordenador Raciel me havia antecipado que o trabalho nesta sede seria especial, pois é esta uma região reconhecida nacionalmente como um berço da cultura ancestral mexicana, um lugar onde estão bem preservadas algumas tradições milenares. E certamente a distância física de grandes centros urbanos protegiam e resguardavam estas tradições. O que impõe aos que tem interesse em acessar este universo sagrado uma grande disposição.

Cheguei a Sede da Huasteca pela manhã, chegava um dia atrasado do que estava no calendário pre-estabelecido pela UVI. A voz já havia corrido entre as sedes sobre a minha presença e sobre projeto de audiovisual que estava coordenando. Cheguei cansado, foram muitas horas de ônibus numa estrada com muitas lombadas. Na Huasteca não havia ainda um lugar para que eu me instalasse, assim me coube ainda, antes de iniciar o projeto, procurar um lugar para me hospedar. Por indicação de alguns alunos, soube que um senhor alugava quarto num bairro próximo a Universidade. Lá me 
instalei. Outros alunos também alugavam quartos com esse senhor, o que proporcionou estabelecer vínculos mais próximo com eles.

A experiência na sede Totonacapan havia me mostrado alguns pontos positivos da metodologia empreendida, mas também eu havia percebido que era necessário restringir a abrangência dos temas abordados. Da mesma forma que iniciamos nosso projeto em Totonacapan, também o iniciamos na Huasteca, ouvindo cada tema pesquisado por cada aluno. A diversidade chamava muito a atenção. Por ser a Huasteca um berço de cultura milenar, nessa região ainda se mantém muitos ritos, assim como muitos mitos. Os nossos alunos se davam conta do patrimônio que tinham em suas casas, em suas comunidades. Junto a outros professores que eram os tutores de nossos alunos, muitos temas vinham sendo pesquisados pelos jovens. Não era mais necessário que alguém de fora estudasse as tradições locais, a própria comunidade vinha se tornando, pouco a pouco, capacitada para olhar para si mesma por um outro olhar, científico, distanciadamente enraizada a realidade local.

Nosso grupo na Huasteca era muito grande, quase 40 alunos em sala de aula. Depois de escutarmos os temas de cada aluno e identificar que estávamos no mês de outubro e que neste mês se realizariam muitos ritos relacionados a Festa de XantoloDia de los Muertos, decidimos todos juntos que seria uma boa oportunidade que todos direcionassem os olhares para estes ritos, e que cada um em seu bairro, casa, comunidade identificasse as práticas e crenças pontuais que nos permitisse gravar e logo compor um documentário sobre a Festa. Alguns alunos desta sede já estavam pesquisando o tema e de imediato trouxeram para o grupo alguns pontos a serem pesquisados mais a fundo.

Quando passei por Xalapa fiquei na casa de David Islas Bravo, responsável pela área da difusão e da comunicação da UVI. David é um aficionado pelo cinema e pela arte audiovisual. Tem uma cultura profunda sobre o tema. Tornamos-nos muito amigos e em sua morada em Xalapa, conversamos muito sobre o projeto UVI, assim como também sobre o projeto que eu coordenava. Nesta permanência em Xalapa, David me passou alguns filmes, algumas produções cinematográfias e também produções indígenas para que eu pudesse levar para as outras sedes. Um destes filmes foi Himalaya, dirigido por Eric Valli. Nessa ficção lançada no ano de 1999, este diretor abordou o tema da importância das tradições, do reconhecimento dos saberes que trazem os anciões. O filme também aborda a questão sobre o vigor e a atualização dos saberes milenários que cabem aos jovens fazer. Himalaya é um filme que retrata muito 
bem como alcançar o equilíbrio entre os saberes que devem ser reconhecidos oriundos do passado, como também sobre a novidade e a manutenção adequada e madura que cabe aos jovens.

Nesta produção o diretor contou com a participação de muitos não atores profissionais. Himalaya ${ }^{18}$ conta com muitos habitantes nativos da região que apenas iniciavam suas vidas como atores de uma obra cinematográfica. Este filme apresentava fielmente algumas realidades que já estávamos tocando e que nossa experiência na Região do Totonacapan já nos havia mostrado sobre o reconhecimento de algumas tradições que sim eram importantes de ser revitalizadas e resguardadas do sistema ocidental. No entanto, também já havia nos mostrado que outras tradições eram importantes de serem transformadas. Himalaya aproximava a realidade do interior veracruzano a realidade de um país oriental. $\mathrm{Na}$ verdade, estas realidades são muito comuns a quase todos os países do mundo, que de algum modo se resumem a questão do diálogo intercultural, que se resumem a percepção, respeito, tolerância que os indivíduos têm que desenvolver em si mesmos para entrar em contato com o diferente, com o novo.

\section{Festa de Xantolo - Día de Todos los Santos}

Iniciamos então nossas gravações e pesquisas sobre a Festa de Xantolo. Os alunos foram trazendo informações de suas casas e comunidades. Mapeavam personagens para então organizarmos nosso cronograma de filmagens. As comemorações e rituais relacionados a Festa de Xantolo estão distribuídas por quase todo o mês de outubro, principalmente a partir da segunda quinzena. Começamos nossas atividades nos primeiros dias de outubro e seguimos até o final do mês, todos juntos.

Os ritos relacionados a esta celebração perpassam por muitas tarefas que são vividas pelas famílias da Huasteca. Há que se preparar os arcos onde são colocados os altares. Para isso preparam-se arranjos florais com folhas de palmeira e as flores que são quase sempre utilizadas nos rituais indígenas, o cempoaxochitl $^{19}$. Nessa ocasião são montados mercados especiais onde somente são comercializados produtos e materiais

\footnotetext{
${ }^{18}$ Himalaya: filme dirigido por Eric Valli, 1999.

${ }^{19}$ Cempoaxochitl: cravo de defunto. Flor utilizada em muitos rituais pelas culturas mesoamericanas.
} 
imprescindíveis para a montagem dos arranjos e dos altares. Nesta ocasião são produzidos os pães dos mortos, específico para anunciar a comunidade que os mortos já estão chegando, para simbolizar a chegada deles.

Com nossa produção tocamos a fundo a complexidade que abarca esta celebração milenar mexicana. Entrevistamos muitas pessoas da comunidade. Nossos alunos levavam os equipamentos para suas casas e nos traziam entrevistas muito íntimas, pessoais, cheias de sentimento. Mas seguramente uma das entrevistas mais elucidativas sobre o tema foi com o Tlamatine Don Atalo Cruz Reina, importante portador dos saberes da cultura nahuatl. Com muito sentimento e pertencimento sobre o tema, recebeu-nos numa manhã, a mim e nossos alunos. Em sua casa estava ele montando seus arranjos de flores e preparando o altar para a "Festa de Xantolo".

Don Atalo com muita serenidade foi relatando-nos, sentido por sentido, significado por significado, simbolismo por simbolismo, relacionado a Festa. Falou-nos sobre os alimentos, sobre os altares, sobre as flores, sobre os cheiros, sobre as músicas, sobre as velas e incensos. Um perfeito Tlamatine, sábio nahuatl, exaltando com nobreza os ritos de sua própria cultura.

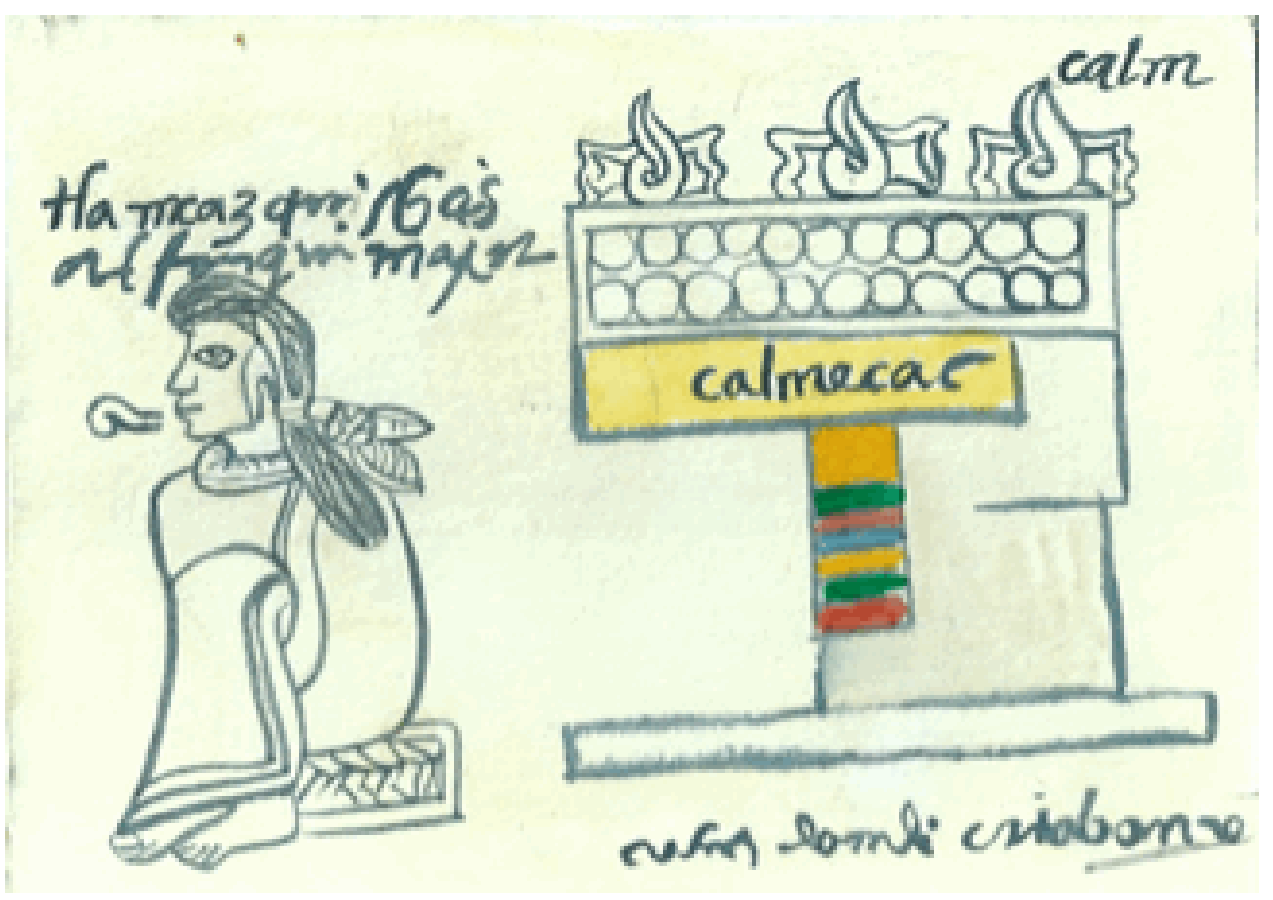

Representación de tlamatine num calmecac. Fragmento del Códice Mendoza, folio 61. 


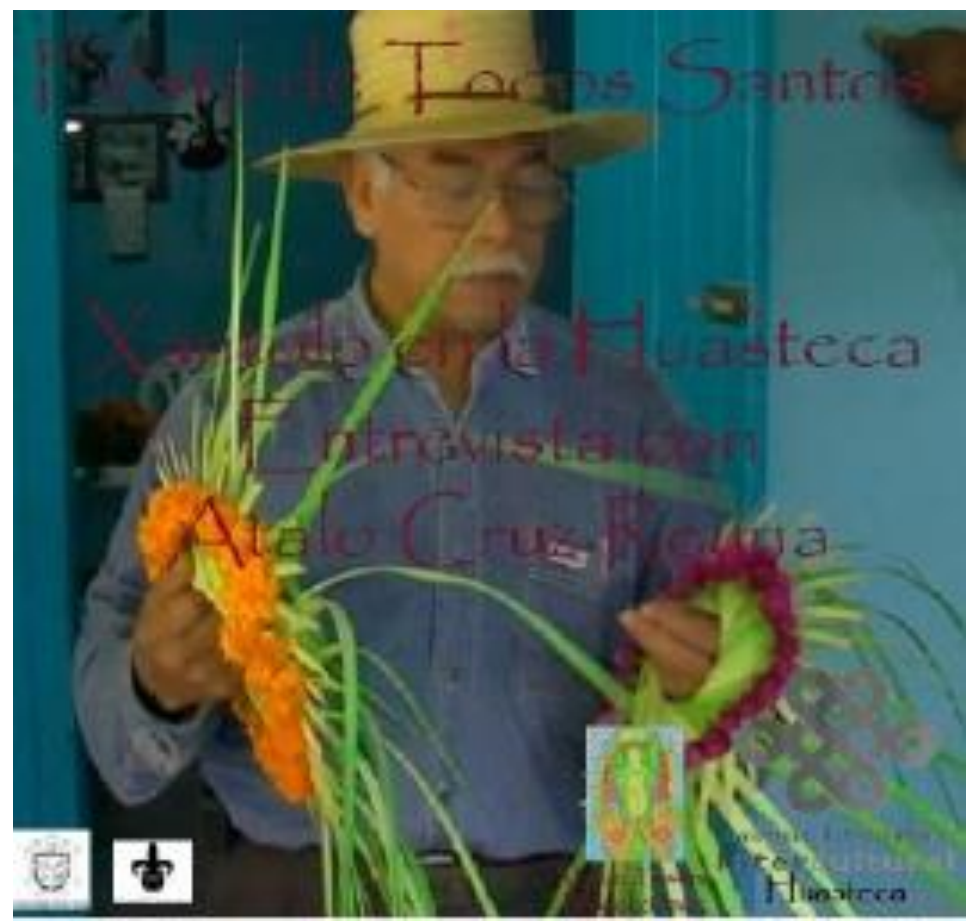

Cartaz do documentário com Don Atalo Cruz Reyna todo ele em língua Nahuatl.

Produzimos três obras audiovisuais na Sede Huasteca, dois documentários e uma ficção. Um de nossos filmes é uma entrevista sobre a Celebração de Xantolo com Don Atalo, toda ela feita em língua Nahuatl. As outras duas criações são também sobre Xantolo, um documentário, onde Don Atalo aparece seguidamente traduzindo e explicando com detalhes a celebração. A outra produção é uma ficção sobre um conto nahuatl. Ambas em espanhol, agora já subtituladas também ao português.

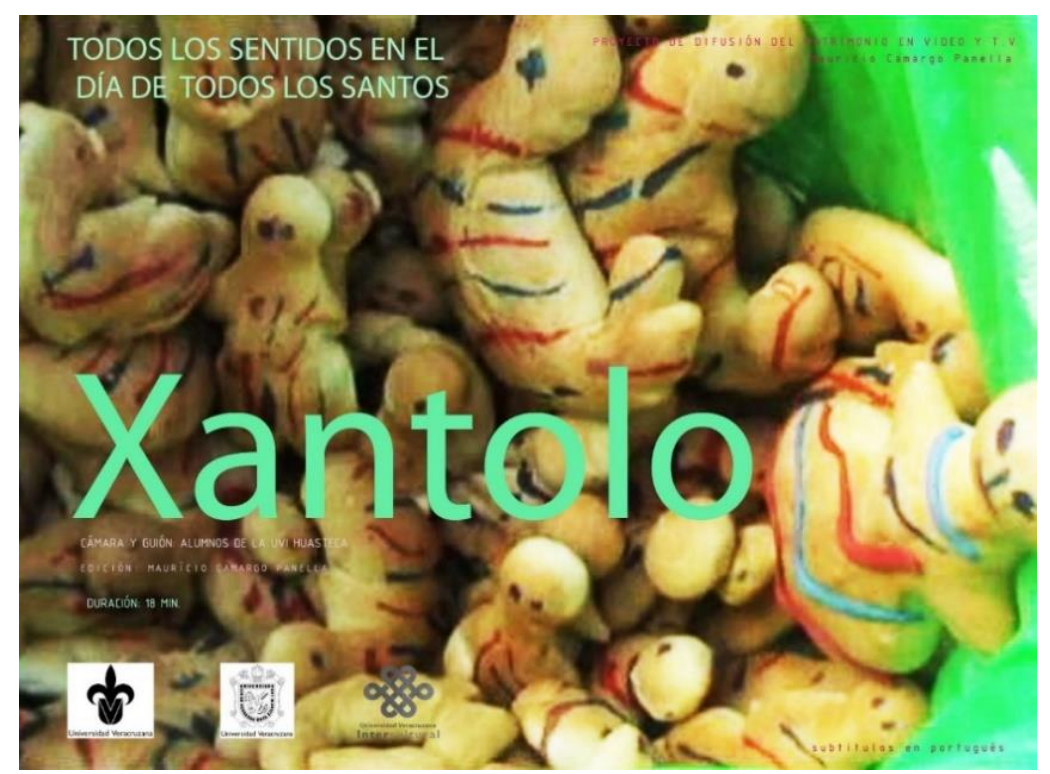

Para ver o filme, acessar o link no Youtube: https://youtu.be/TwNIbxE1SWs 
Don Atalo quando se detêm a falar sobre muitos dos pontos da celebração aparenta estar sempre estar muito concentrado. No exato momento em que iniciaria a falar sobre a importância da queima de essências, se detêm diante ao altar, pega seu copalero $^{20}$, queima em suas brasas o copal $^{21}$, respira profundamente, e como se algo em seu interior tivesse mudado, Don Atalo, ereto, diz que até aquele momento estava passando informações sobre a Celebração, mas que no momento em que queimou o Copal instantaneamente ele mudava seus sentimento e o modo de expressar seu conhecimento. Don Atalo nos falou de como o aroma do Copal levara a ele a um estado de comoção diferenciado e que a partir da incorporação desta sensação, consequentemente as suas palavras sairiam mais floridas, e poderiam da mesma forma con-mover mais as pessoas. Ou seja, pelas palavras emitidas com sentimento, Don Atalo conseguia por em movimento a alma e os corações daqueles que escutavam suas palavras.

\section{Pensar e sentir}

Na língua Nahuatl o termo Tlamati quer dizer saber e sentir. Os textos indígenas sejam eles expressos pela oralidade ou em forma visual mostram uma estruturação onde a função de sensibilização são de extrema importância. No mundo pré-colombino uma mensagem não era bem compreendida se não fosse sentida. A palavra em nahuatl Mati revela dois sentidos: saber e sentir. Don Atalo exercia muito bem seu papel como Tlamatini sabendo comover os seus ouvintes. Don Atalo dizia palavras floridas.

Ele nos falou sobre as flores, sobre os arcos também. Os arcos de oferenda são parte fundamental para os ritos desta celebração. São neles que são colocadas as fotografias dos parentes que já partiram, são neles que são postas as velas, os alimentos, os rezos. É a partir da construção dos altares, dos arcos, que os familiares iniciavam os preparativos para receberem cada qual seus mortos em suas casas. Don Atalo falou muito sobre as flores de cempoaxochitl, que simbolizam a conexão que se estabelece com o mundo mais sensível, invisível ao mundo real. Desde o dia 30 de outubro as famílias iniciam a erguer seus altares. Para isso em cada comunidade, nesta época, acontece um mercado especial para que todos possam comprar seus artigos rituais que compõem os altares/arcos.

\footnotetext{
${ }^{20}$ Copalero: incensário onde se queimas as ervas ritualísticas para limpeza e cura.

${ }^{21}$ Copal: resina de árvore utilizada para defumar e curar as pessoas.
} 


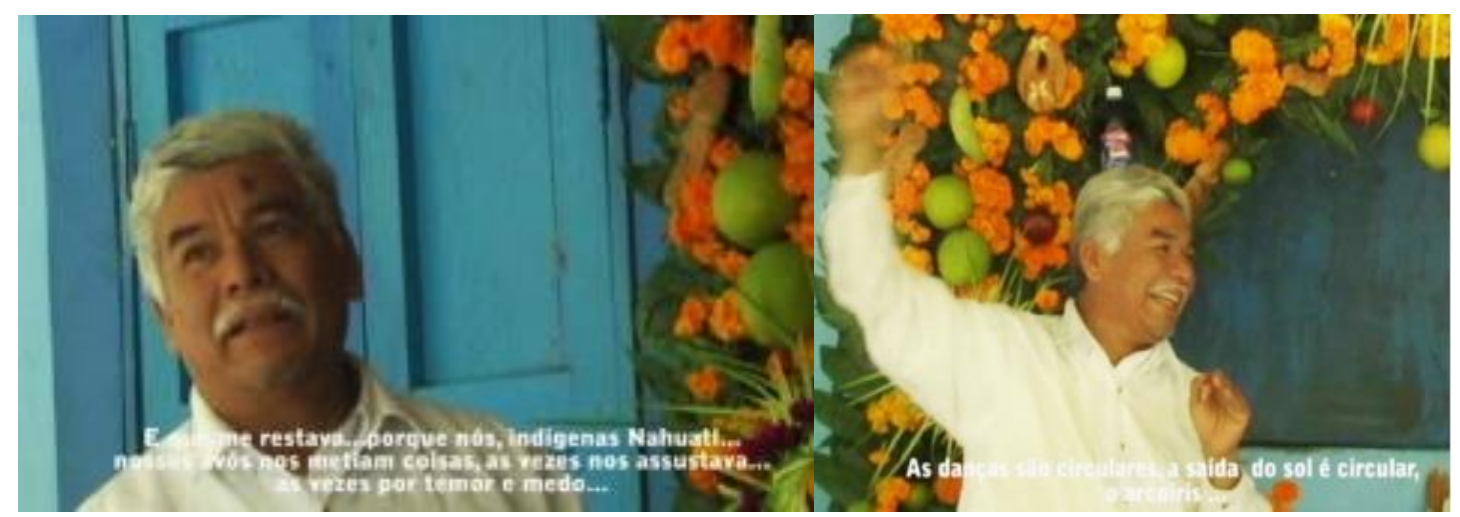

Don Atalo Cruz Reyna- TlamatineNahuatl explicando os simbolismos da Festa de Xantolo.

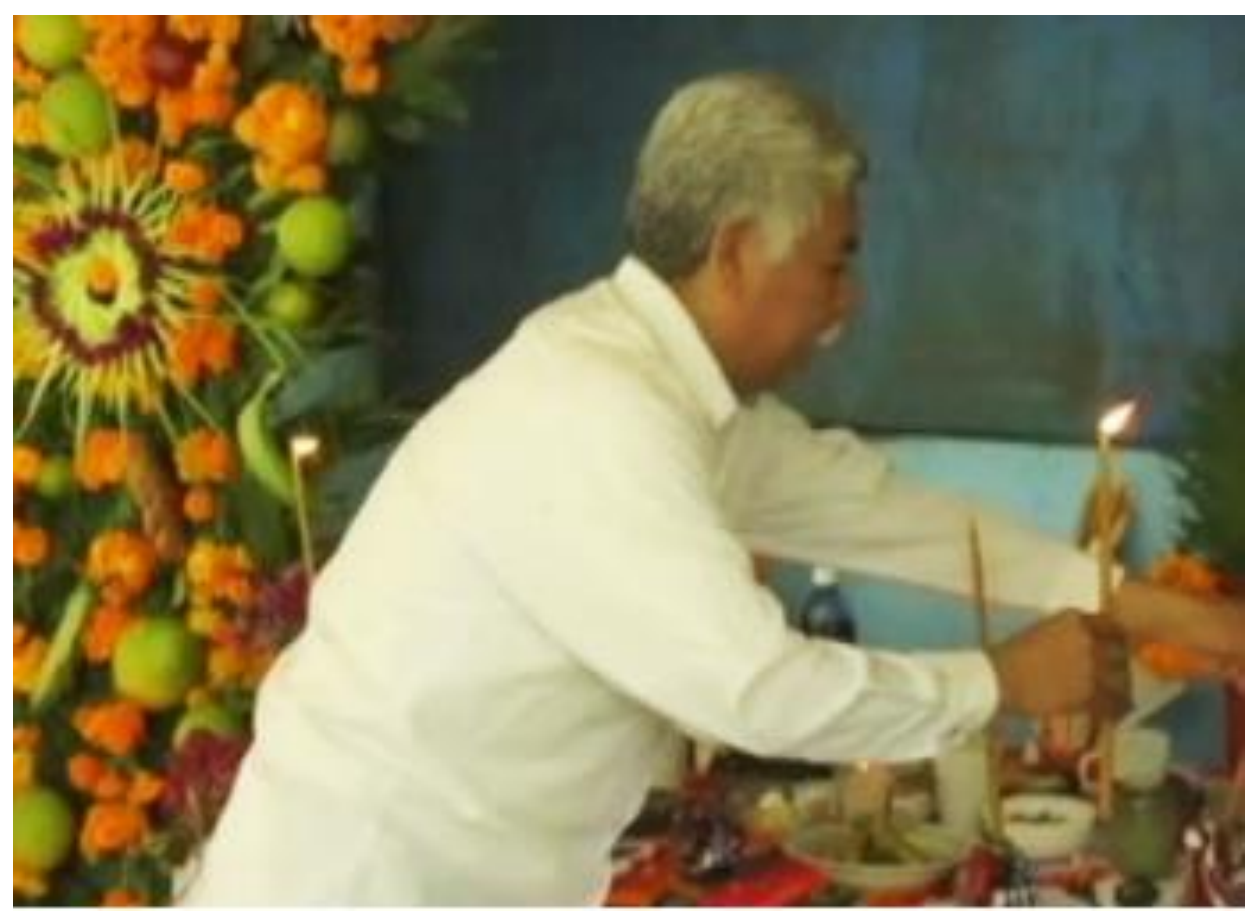

Don Atalo Cruz Reyna acendendo velas em seu arco/altar.

O processo de criação artística está presente em muitas das atividades cotidianas do mundo indígena mexicano. Há ocasiões em que são celebrados os ritos são os momentos onde mais está explícita uma cosmovisão fincada no compromisso de construir uma linguagem poética, uma linguagem florida, uma expressão que comova. Assim podemos ver, tanto na fabricação dos copaleros, dos porta-velas de cerâmica que nesta ocasião são comercializadas nas feiras públicas, na produção de velas de cera de abelha decoradas com papel de seda colorido. Pode-se ver essa linguagem florida na 
construção dos arcos, dos altares. Assim como na execução de sones ${ }^{22}$ que são tocados em muitas ocasiões.

El hecho de que La sensación tuviera que estar presente, de alguna manera, em la configuración cognitiva que el indígena tenía de algo, hacía que La idea "hiciera cuerpo" com lo que intentaba representar. En este contexto, lo simbólico, o mejordicholo "símbolo- lógico", las afinidades visuales o sonoras, la "simbiosis" semántica de lãs palabras, la retórica y La poesia permitían al saber cristalizarse sobre La palabra de los hombres. (Patrck, 2005: 523)

No alto dos altares se coloca o "pão do morto", um pão em forma de boneco que é produzido somente nesta data. Este boneco tem várias funções, como ser uma oferenda, assim como também sendo uma representação dos seres já falecidos. É muito comum nas padarias das comunidades da huasteca veracruzana encontrar padeiros fazendo o pão de morto e assando em seus fornos caseiros.

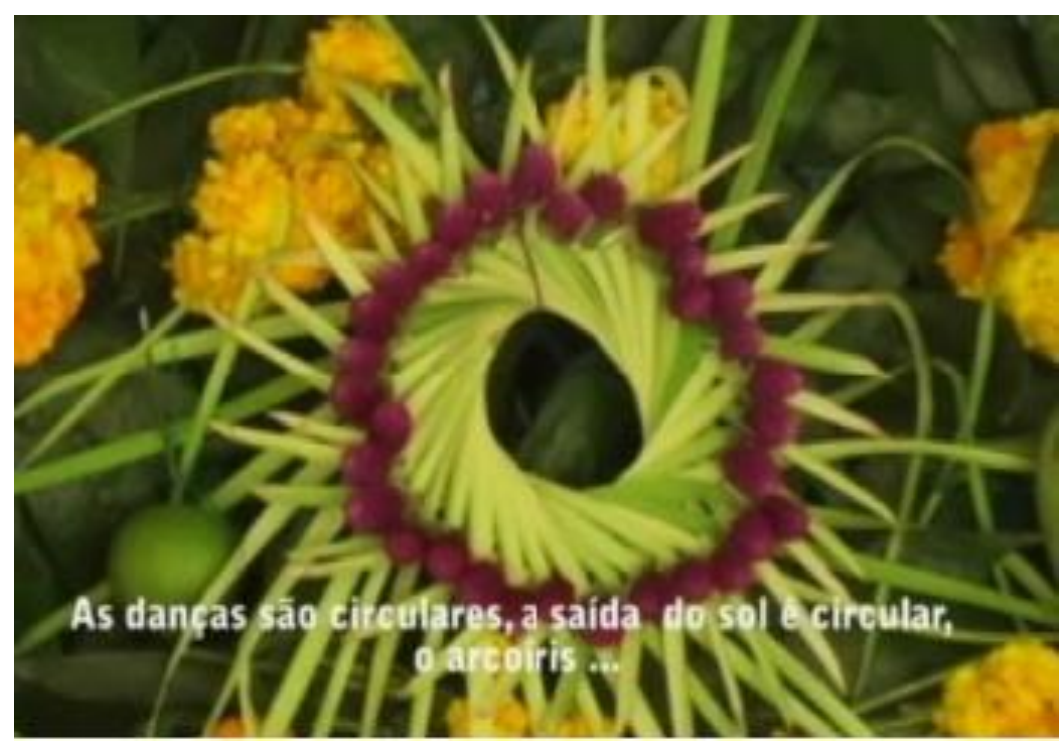

Xochiyehualli: adorno floral com Cempoaxochitl.

Quando Don Atalo nos falou sobre a importância da flor de Cempoaxochitl, mencionou como que o perfume, como que o olor da flor sensibiliza as pessoas. Dissenos que esta flor é a "Flor que comove" o coração e as mentes das pessoas. Ao falar sobre os significados que são atribuídos aos enfeites criados com as flores que são colocados nos altares, os Xechoyehualli, Don Atalo Cruz Reyna apresenta o indígena como um artista que compreende a natureza e pela expressão artística a representa, como já mencionamos em outro momento. Don Atalo fala que a representação deste

\footnotetext{
${ }^{22}$ Sones: Muitas das manifestações culturais e ritualísticas do México são expressas pela composição de sones. Para cada etapa de um ritual pode ser executado um sone específico.
} 
arco florido é a representação do arco íris, do movimento do sol, da terra, representando também as danças circulares, o sol que nos dá a luz. Don Atalo seguidamente relaciona as artes de oferenda que embeleza os altares com representações metafóricas com a vida humana. Ao exemplo do arco Xochiyehualli que ele expõe também o simbolismo do ciclo de vida que todos nós temos, de início e fim de nossa existência terrena. A própria língua nahuatl é uma expressão simbólica e metafórica que expressa muitos significados em sua construção linguística

Todas essas representações que são expressas pelas oferendas em forma de artesanato, em forma de alimento, em forma de música ou em forma de dança aproximam as gerações mais jovens às tradições que são perpassadas desde os tempos pré-colombinos pelos sábios Tlamatinis que tatuaram na alma mexicana este respeito pela tradição ancestral. Este é um sentimento comumente sentido nos pueblos veracruzanos: o respeito pela palavra de um ancião, pela palavra florida, pela palavra que comove.

A Sede da UVI Huasteca realmente conta com a presença deste sábio que sabe comover por suas palavras e pelo conhecimento que tem sobre as tradições. Don Atalo está sempre presente nas atividades com os alunos da UVI Huasteca. Sua presença é imprescindível para solucionar dúvidas e para acessar os significados da cultura nahuatlhuasteca. No México e principalmente nas áreas rurais como estas em que atuamos, a palavra dos avós continua sendo recebida com honra. Por mais que outros discursos e linguagens sejam absorvidas e escutadas, ainda em muitas regiões da República mexicana, as palavras emitidas por senhores como Don Atalo, são bem recebidas. "Lo que dijeron los abuelos" es um dixit Magister inapelable, sometido a La erosión cultural Del tiempo mas no a la especulación de los hombres. "23

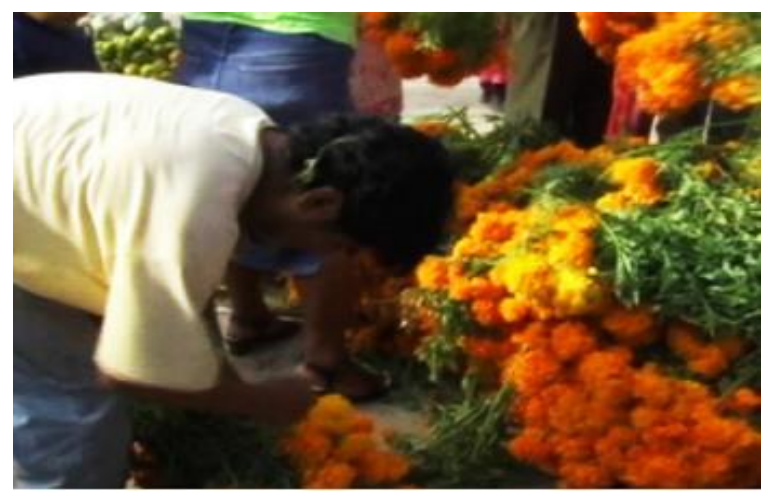

\footnotetext{
${ }^{23}$ Johansson, Patrick: El sentido y los sentidos en la oralidade náhuatl pre hispánica. Revista Acta poética, pag. 524, 2005.
} 


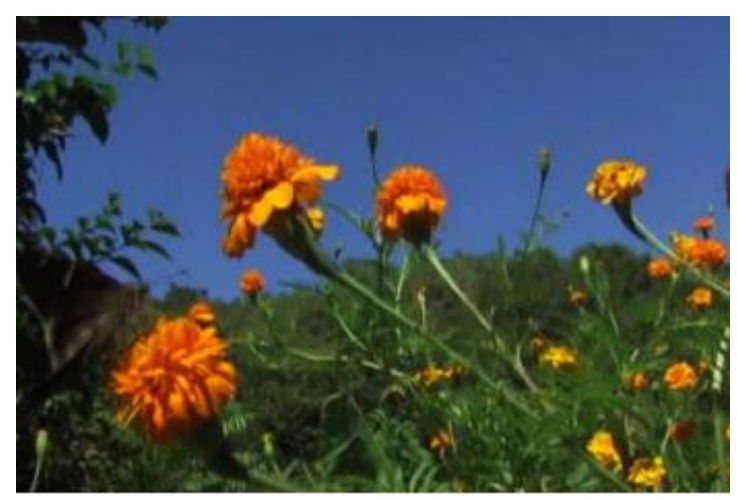

Plantação de Cempoaxochitl e mercado de flores em Ixhuatlán de Madero.

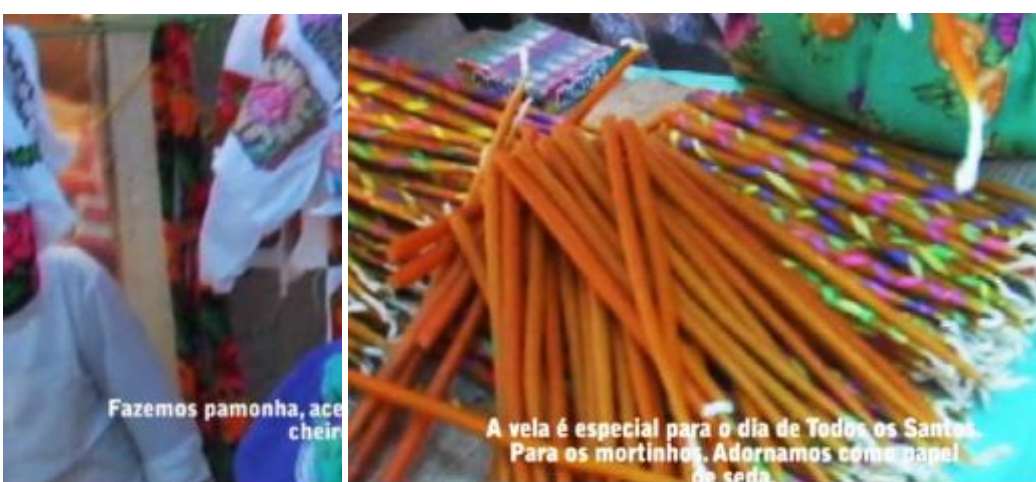

Vendedora de velas de cera com papel de sede em mercado.

Mas também fomos fazer visitas para gravar entrevistas com muitas outras pessoas, principalmente na comunidade de Ixhuatlán de Madero. Uma das pessoas entrevistadas foi uma senhora que havia visto uma criança já falecida embaixo do altar numa celebração do Dia dos Mortos. Esta senhora narrou com detalhes a conversa que teve com a criança, contando aos jovens como era importante fazer as oferendas para os mortos. Principalmente para que eles não se sintam desprezados pelos os parentes vivos. O culto aos mortos é feito tanto como um ato de rememoração da presença dos parentes queridos, mas também como uma oferenda para que os mortos não se sintam esquecidos, e assim, não se enraiveçam com os parentes vivos. Don Atalo deixa muito claro isso quando conta que os seus avós muitas vezes contavam histórias assustadoras sobre a visita que alguns mortos fazem a seus parentes em forma de pesadelo ou aparição sombria.
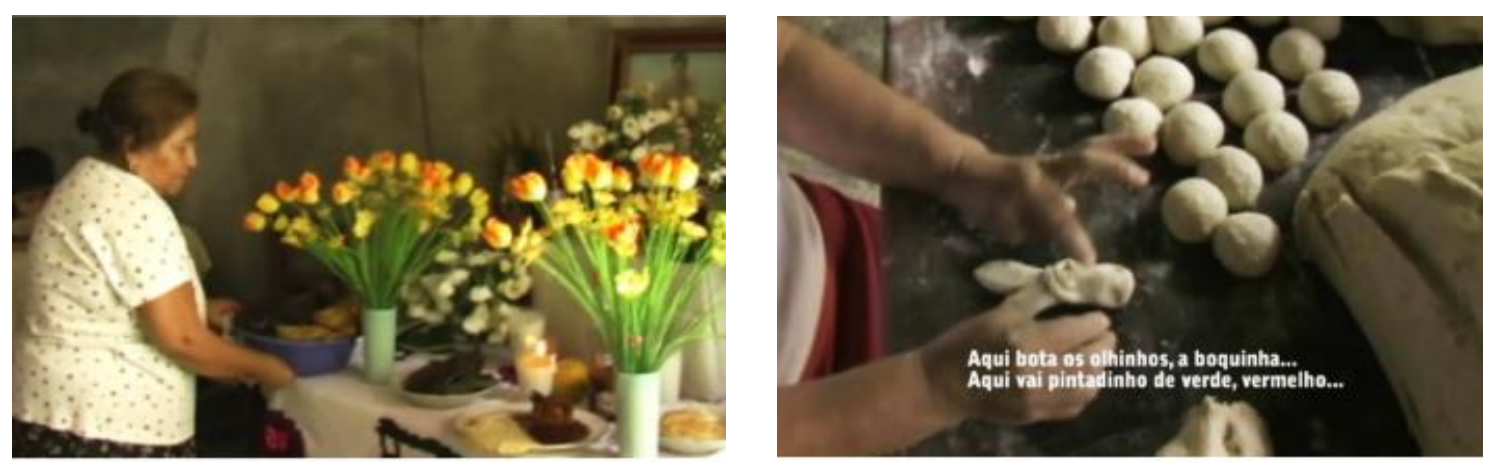


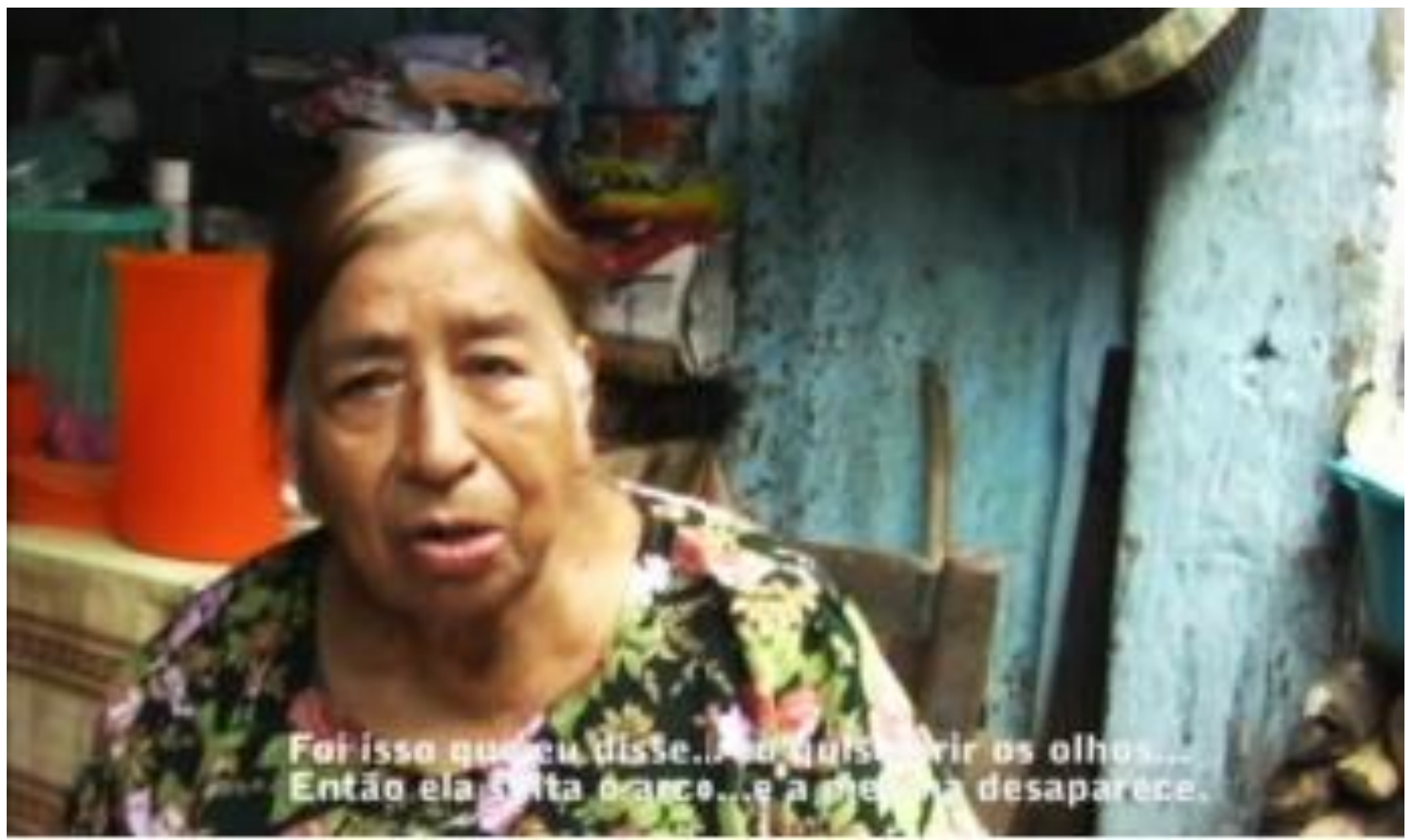

Imagens de entrevistados preparando e falando sobre o ritual de Xantolo.

Muitas pessoas da região de Ixhuatlán de Madero, que os alunos haviam feito entrevistas sobre os significados da Festa de Xantolo, mencionaram esse aspecto tenebroso relacionado a preparação de oferendas como meio de sossegar os mortos, os deixando felizes no mundo invisível. Devido aos muitos registros, os alunos da Sede Huasteca se animaram a produzir também um curta metragem em forma de ficção, em que eles atuariam neste conto sobre Xantolo. Essa única produção em forma de ficção em nosso projeto junto a UVI foi intitulada por Nunca mueres solo vives - Cuento verídico sobre Xantolo. Seguramente recolhemos do filme Himalaya o incentivo necessário para a criação deste produto.

Nosso roteiro para a construção do documentário sobre Xantolo era um roteiro de entrevistas, um roteiro completamente aberto pois não se sabia quais as informações que iríamos recolher. No entanto nossa produção do curta, a situação já era outra. Já estávamos trabalhando juntos há dias, já tínhamos coletado muito material, e todos estávamos compartilhando e discutindo sobre o tema. Já havíamos identificado nossos câmeras, nossos captadores de áudio. Assim como na Sede Totonacapan, já sabíamos quem dos alunos falavam e entendiam perfeitamente bem as línguas originárias, assim pudemos definir como trabalharíamos em equipe para a produção do curta. 
A própria estrutura da construção de um curta metragem se aproxima muito mais a linguagem cotidiana utilizada no dia a dia dos alunos. A proximidade deste discurso com o discurso de um mito desperta uma construção de um trabalho onde as pessoas se apropriam com mais facilidade da ferramenta do audiovisual. Se tornou muito mais fácil a adesão de todos os alunos na produção do filme Nunca mueres solo vives.

\section{Nunca mueres solo vives}

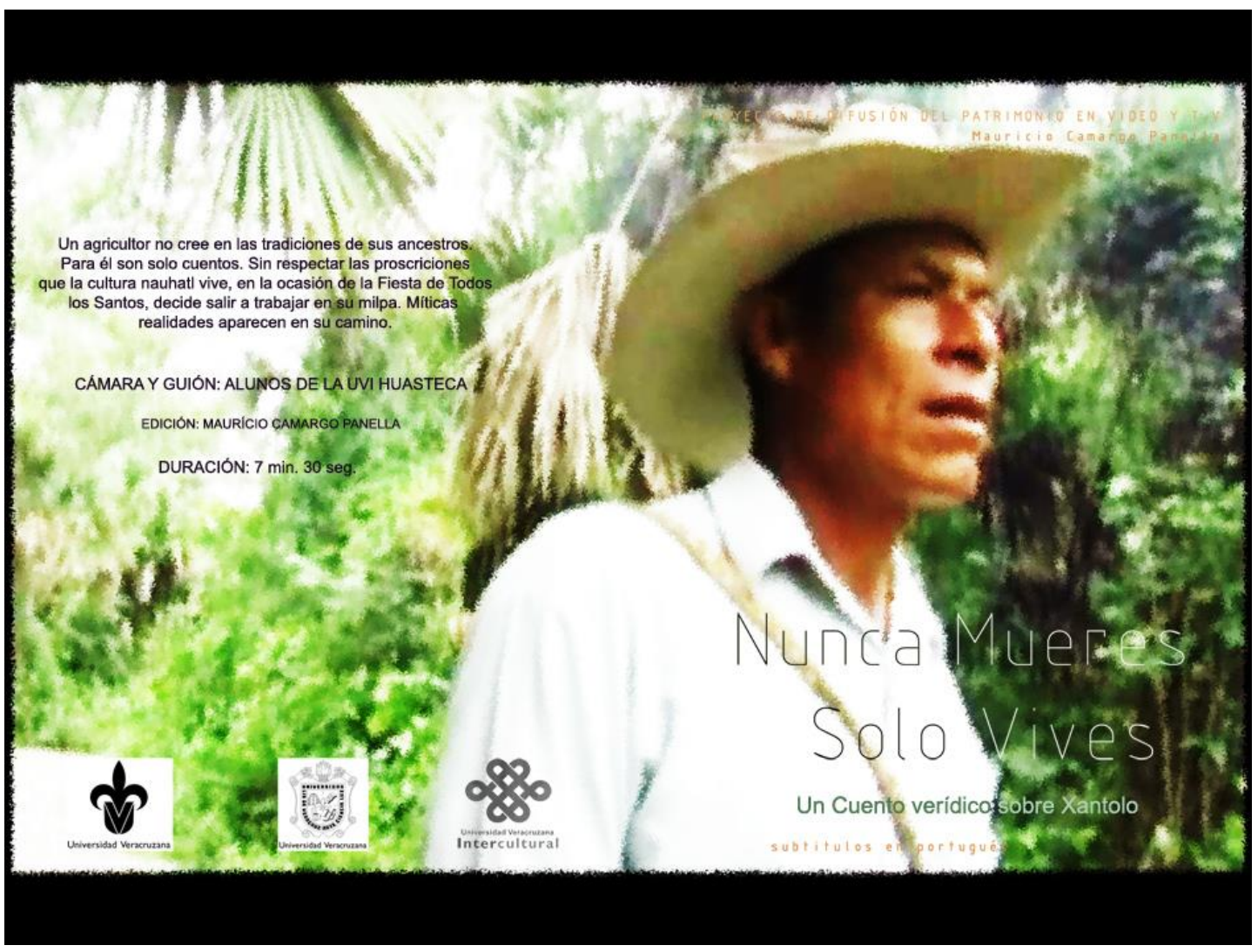

https://youtu.be/RYvpD4g35dI

Os alunos se dividiram em grupos para que cada equipe pudesse se responsabilizar por uma atividade na produção. A primeira função que, de alguma forma foi grupal, foi a construção da narrativa do conto sobre a Festa de Xantolo onde aparecia um personagem que não respeitava as tradições e que no dia de Todos os Santos não fazia as oferendas tradicionais, e então sobre ele recaia uma maldição. Os alunos ouviram várias versões sobre a mesma ação e punição e recriaram um diálogo entre alguns personagens. 
Tínhamos a equipe responsável pela gravação, dois câmeras-man, uma equipe de captação de áudio, uma responsável pela construção do cenário, outra pela maquiagem e figurino e uma que construiu os diálogos. Precisávamos de atores e de um cenário. Entre os próprios alunos definimos quem atuaria. E uma aluna ofereceu a casa de seus pais como cenário, já que era um ambiente bem tradicional, com casa de palha, criação de animais, plantação de milho, perto de uma serra. Definimos dia e hora e nos encaminhamos todos para passar o dia.

A ideia inicial era gravar tudo num só dia. No entanto, quando chegamos na casa de nossa aluna resolvemos realizar a última entrevista com seu pai. Sentamos-nos na varanda, todos em círculo. Era uma cena linda, pois ali, pela primeira vez estávamos todos juntos realizando uma entrevista em companhia dos pais de uma aluna e também com seus avós. Um momento único: todos a ouvir as histórias das tradições do povo Nahuatl. Para mim em especial foi um dos momentos ápices de minha atividade profissional no projeto, pois o senhor que nos dava a entrevista era muito carismático, mediava sua entrevista com falas em nahuatl perguntando a seu pai que não falava e nem entendia bem o espanhol. Ao lado estava a avó de nossa aluna triturando os grãos de café recém colhidos para nos preparar um desjejum. Era realmente uma cena tradicional. Vivíamos todos o filme.

A cada palavra mencionada pelo pai de nossa aluna todos se maravilhavam, todos atentos as informações que ele nos repassava. Aquela família compreendia muito bem a importância de nosso trabalho e estava disposta a nos ajudar. Ali todos éramos um. Num determinado momento da entrevista o pai de nossa aluna conta o mesmo conto verídico que mencionava a história de um habitante da região que não havia cumprido as tradições e que sobre ele lhe havia caído uma maldição. Mas a forma como ele narrou o conto foi tão verídica, tão fiel... A forma como ele mudava as vozes dos personagens do conto... E sem que eu precisasse falar nada... um aluno se aproximou de mim e perguntou: "Professor, porque não convidamos o pai dela para ser o protagonista de nosso filme?"

Todos estávamos de acordo com aquela nova possibilidade. Somente teríamos que perguntar aos pais de nossa aluna, que imediatamente aceitaram. $\mathrm{O}$ momento era tão magnífico que decidimos reformular os diálogos e ficar mais um dia na casa deles para que os pais de nossa aluna pudessem ensaiar. 
No dia seguinte acordamos todos, tomamos café e iniciamos os preparativos para a produção do filme. Durante todo o dia realizamos todas as cenas. O envolvimento era tremendo, até mesmo dos avós de nossa aluna. Os alunos estavam todos emocionados. Assumiam a responsabilidade de suas funções com muito mais alegria, em comparação a produção do documentário. Realmente a linguagem do cinema se equiparava a linguagem mítica, ritual, cênica que se vive cotidianamente entre as populações mesoamericanas.
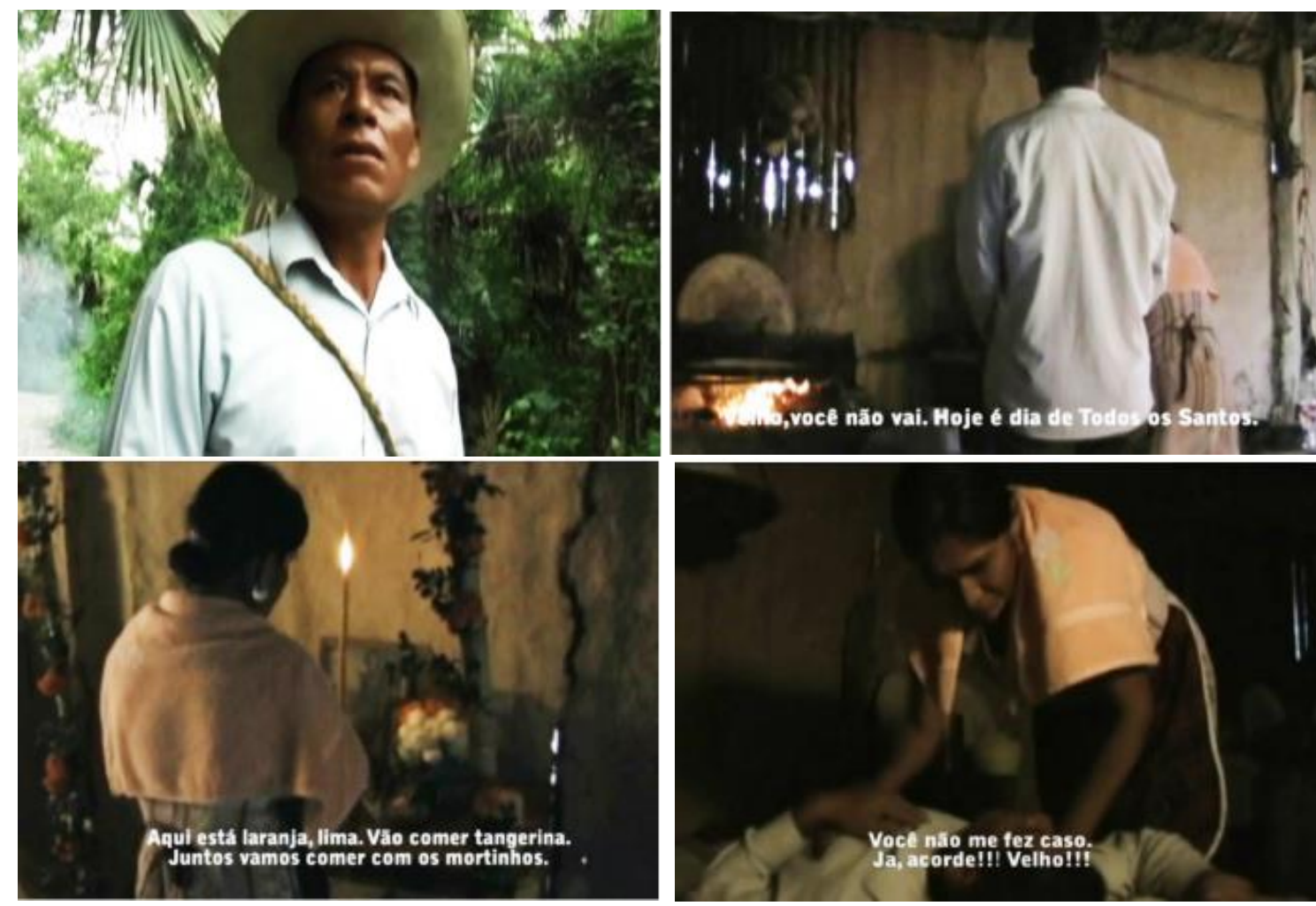

Imagens das gravações do curta Nunca Mueres Solo Vives.

Por todo o dia gravamos as sequências das cenas. Pela encenação do conto, todos vivíamos a tradição contada oralmente e registrada em formato audiovisual. Tínhamos o relato em forma de documentário e agora o estávamos colocando em forma de ficção. A participação da família de nossa aluna enaltecia ainda mais nossos propósitos. Seguramente até os dias de hoje esta família tem na lembrança, os momentos vividos. O exercício de trabalhar com não atores profissionais foi muito interessante e vivaz para todos. 
No final da tarde, quando tomávamos as últimas cenas, o coordenador da Sede Huasteca, Rafael Nava Vite, também indígena nahuatl, chega para acompanhar nosso trabalho. Podíamos ver em seus olhos a alegria em desenvolvermos aquela criação artística, que fundamentava os princípios das atividades pedagógicas da UVI.

\section{Ritual de colheita do milho}

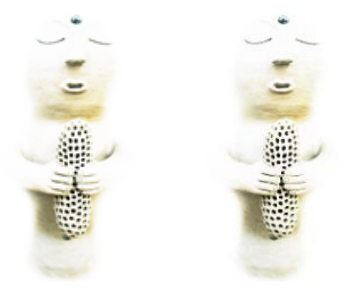

Durante a minha permanência na Huasteca ainda viveria rituais imprescindíveis para a minha formação profissional, artística e espiritual. Quando saí do Brasil, levei comigo uma espiga de milho que me acompanhou por toda itinerância do projeto. Numa tarde aquela espiga brasileira abriria para mim uma oportunidade sem igual de vivenciar os ritos relacionados a sacralidade milenar que este grão ocupa na Mesoamérica.

Duas alunas minhas vieram retirar algumas dúvidas sobre uma atividade que realizaríamos no dia seguinte. Uma delas, Lídia, ao ver em meu quarto uma espiga, me pergunta porque que eu trazia aquele milho comigo. Eu conto para ela algumas das histórias que eu havia até então vivido com relação ao milho, tanto no México como no Brasil. E digo que já de muitos anos eu tinha adquirido o costume de sempre ter milho entre meus pertences. Lídia então naquela tarde me perguntou se eu não estaria disposto a acompanhar um ritual que seu cunhado estaria fazendo no final de semana seguinte numa casa de costumbre ${ }^{24}$ por ocasião da colheita de milho que algumas famílias estavam por realizar.

Eu aceito o convite e me preparo para empreender uma viagem até a casa dela, perto do Município de Chicontepec. Era um sábado, saio bem cedo de Ixhuatlán de Madero. Chego a casa de Lídia antes do almoço. Espero que a família dela organize alguns pertences que teriam que ser levados para o ritual e então saímos num caminhão para um sítio aonde estava já um grupo grande de pessoas, todas elas da cultura nahuatl.

\footnotetext{
${ }^{24}$ Casa de Costume: Local aonde as famílias organizam os rituais tradicionais.
} 
Pouco se falava o espanhol. Lídia me apresenta a todos e principalmente a seu cunhado, que era quem estaria dirigindo o ritual ao lado de outros Curandeiros de Maiz ${ }^{25}$. Lídia explica a seu cunhado o objetivo do nosso projeto e pede permissão para que realizássemos as nossas filmagens. O que definitivamente não o fizemos. Para mim aquele momento tinha que ser vivido com toda a integridade, sem preocupar-me com ângulos. Lídia não era nossa aluna mais interessada em aprender a manusear os equipamentos. E naquele dia nenhum aluno nos acompanhava. Não era um dia de trabalho. Durante o projeto, eram raras as ocasiões que eu pegava a câmera para filmar, minha função sempre era como tutor. E naquele dia definitivamente não seria a ocasião para estar diante do ritual empunhado com o equipamento.

Novamente naquela tarde pude acompanhar como que a arte, o processo criativo faz parte do cotidiano ritualístico indígena. A montagem dos altares, a organização dos elementos. Da mesma a forma como a cena ritual era organizada. Havia um cenário produzido para que ocorresse a celebração. Estavam lá todos os personagens, quase todos anciões e anciãs com suas roupas tradicionais. As mulheres com seus vestidos bordados muitas vezes por elas mesmas, nos quais transpõem para suas roupas as imagens das flores da flora e da fauna de sua região. Mostra clara, emocionante de como esta cultura reconhece e leva em sua alma e inclusive em suas vestes, o próprio patrimônio natural e também cultural.

$\mathrm{O}$ ritual iniciou no meio da tarde e se estendeu por toda a noite alcançando o amanhecer. Os elementos ritualísticos que eram construídos com beleza, arte e sensibilidade foram sendo apresentados para mim como se tudo aquilo já fizesse parte de minha alma. Também nos rituais de colheita de milho as flores de Cempoaxochitl são utilizadas tanto para adornar esteticamente como para comover as pessoas com seu olor. Os enfeites florais eram produzidos por senhores, muitos deles, anciões. Aquelas mãos enrugadas tão delicadas tocando e fazendo arcos e buques de flores.

\footnotetext{
${ }^{25}$ Curandeiros de Maiz: curandeiros que trabalham com as sementes de milho para ler o passado e fazer prognósticos futuros. São muitas as formas pelas quais se utilizam as sementes para adivinhação.
} 


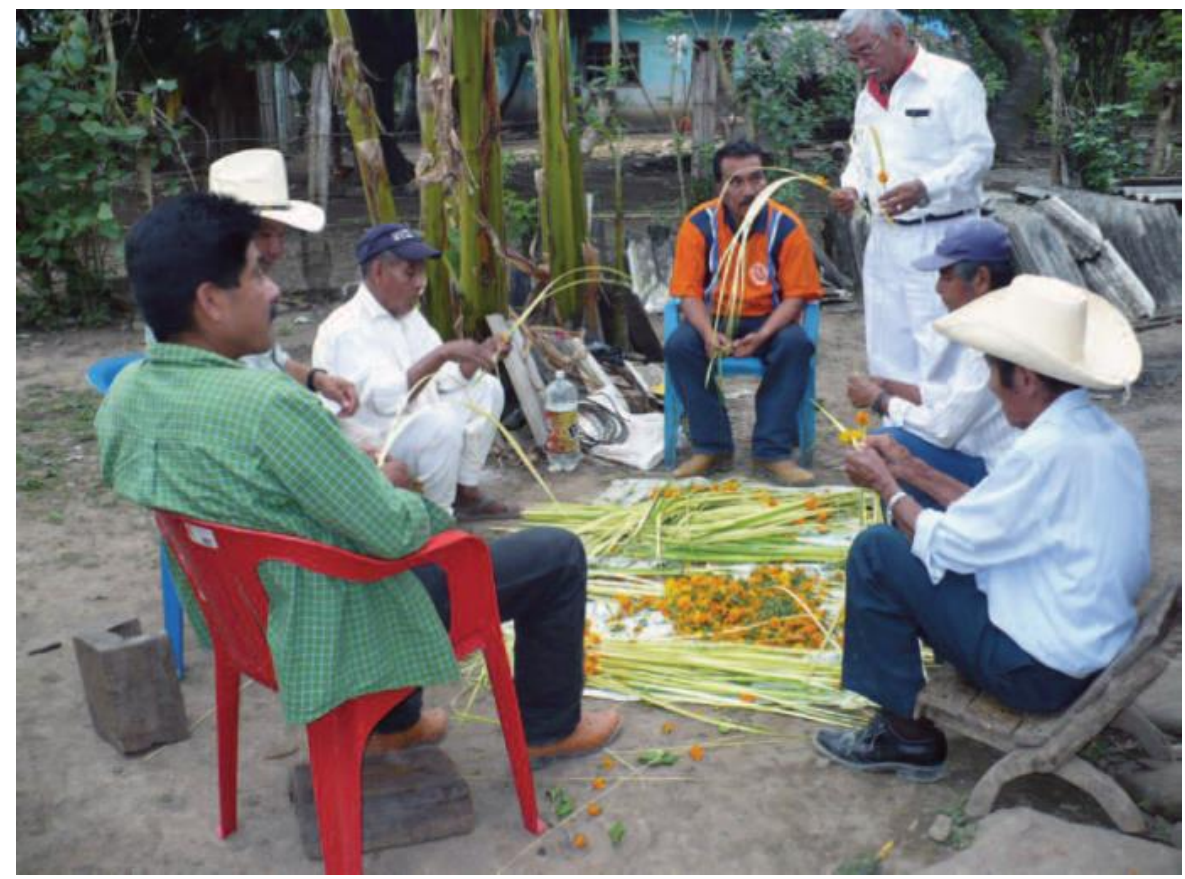

Fotos feitas por Rafael Nava Vite em outro ritual do milho.

Não é minha intenção construir uma etnografia sobre os rituais ou manifestações que o projeto permitiu que vivêssemos. O que quero é trazer são reflexões sobre como o processo criativo é vivo nas tradições indígenas e que, com nosso propósito de criar coletivamente por meio do audiovisual, foi - nos permitindo acessar essas manifestações criativas. E assim demarcarmos a importância que ocupa em nossas vidas o estado criativo e transmutador que a arte promove. Na arte ocidental muitas vezes a função de comover as pessoas ficam restritas a classe dos artistas. No contexto indígena a arte aparece como forma de embelezamento do cotidiano, onde homens, mulheres, anciãs e anciões são mestres, sem necessariamente ocupar esse posto de forma hierárquica.

A cosmovisão das culturas indígenas mesoamericanas, em especial a cultura nahuatl está ancorada por modos de construção de linguagens e modos de comunicação que favoreçam tanto ao emissor quanto ao receptor da mensagem a predisposição de diálogo com o próprio coração.

Por muy lógico y racional que fuera el cuestionamiento reflexivo, el pensamiento indígena lo concebía como un diálogo entre el intelecto y La sensibilidad, entre la mente y el corazón. Reflexionar era dialogar com su corazón neyolnonotza, es decir, en este contexto, fundir La argumentación intelectualmente configurada em el crisol de La sensibilidad.(Johansson, 2005: 525) 


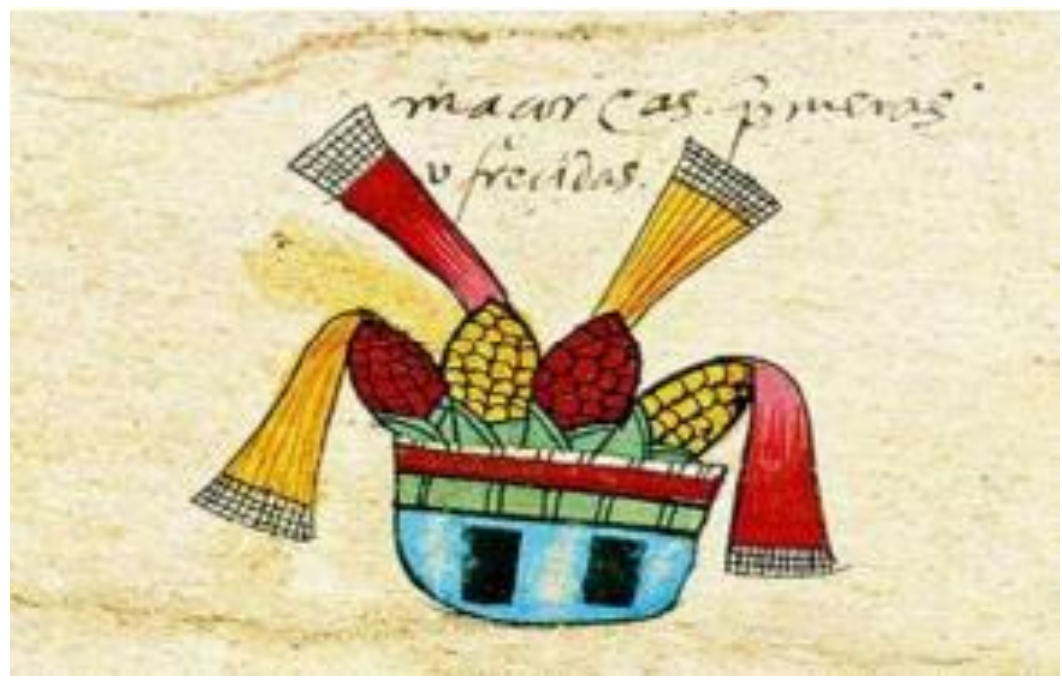

Códice Borbónico, lâmina 23.
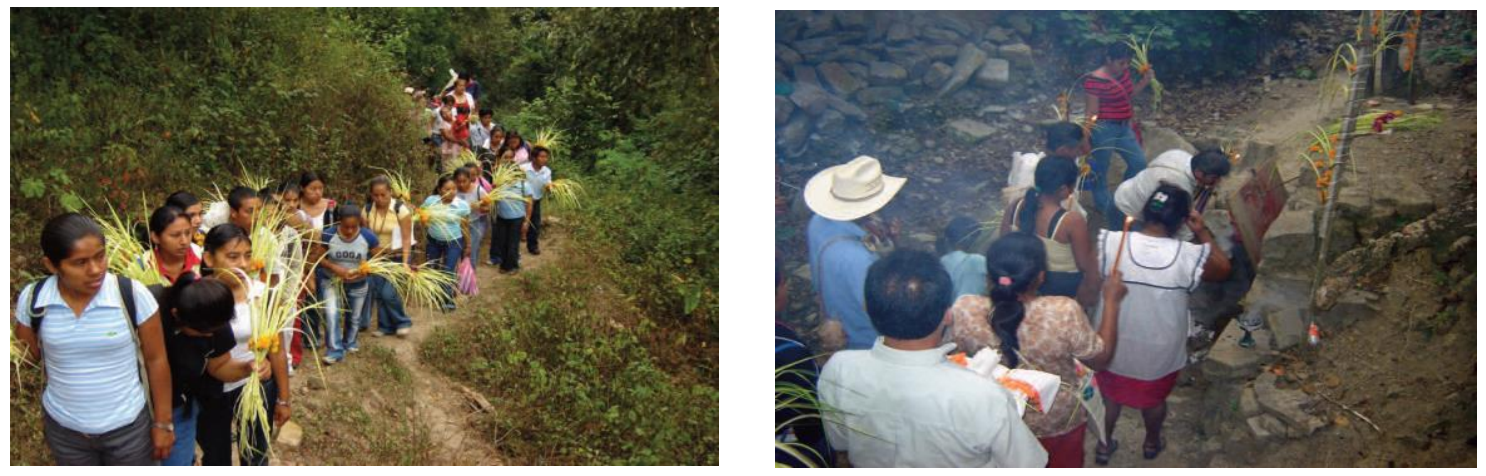

Imagens da caminhada em direção a realização de uma oferenda num poço. Imagens Rafael Nava Vita.

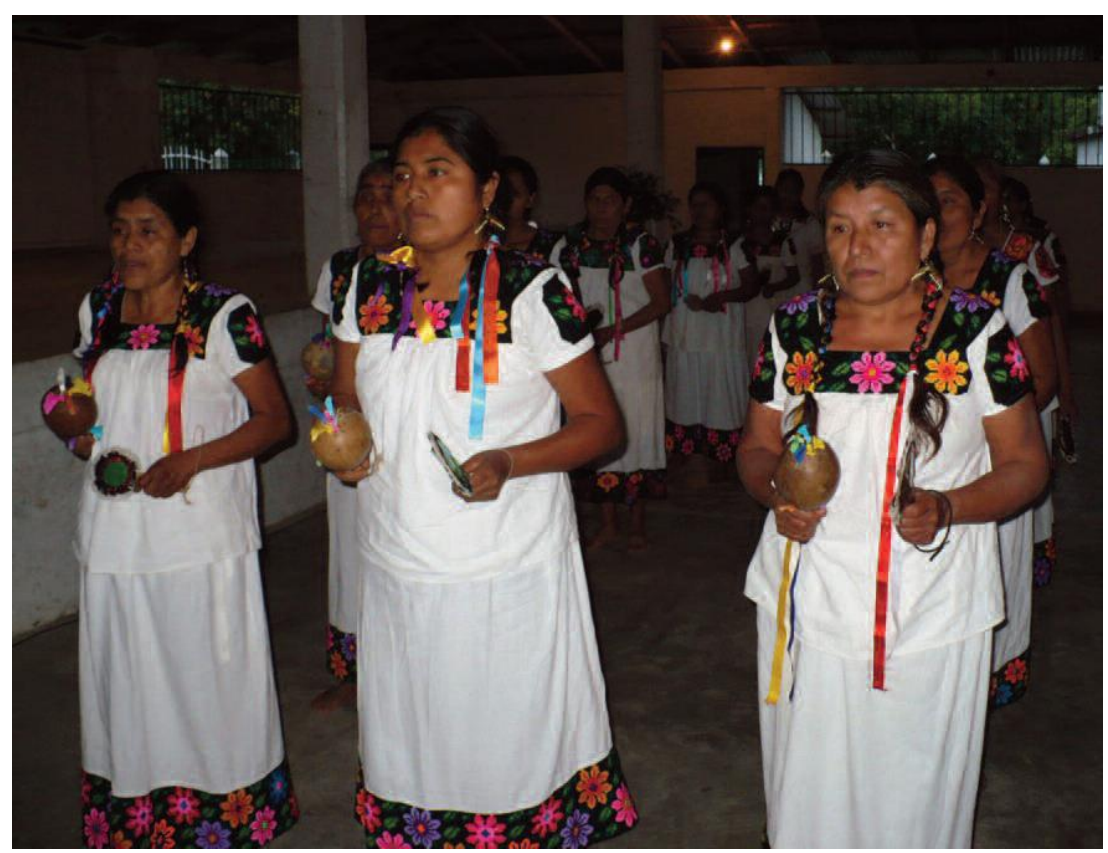

Fotos Rafael Nava Vita em outro ritual com nossos alunos. 

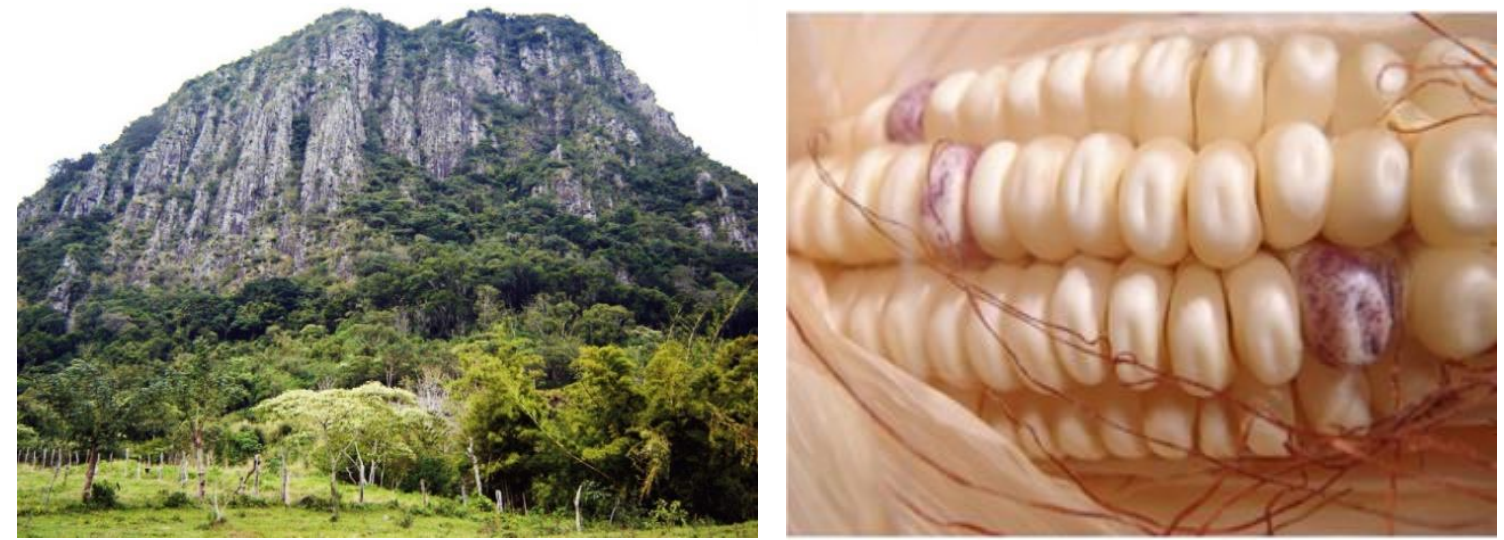

Cerro ceremonial Postektitla, e milho pérola. Foto: Rafael Nava Vite, Maurício Panella.

Nem eu, nem Lídia fizemos gravação alguma, mas outra aluna, Eugênia Jerônimo Hernandez, naquele mesmo final de semana, havia levado outro equipamento para outro ritual de colheita do milho. Muitas das imagens que ela gravou mostravam cenas parecidas com as quais eu e Lídia tínhamos acompanhado.
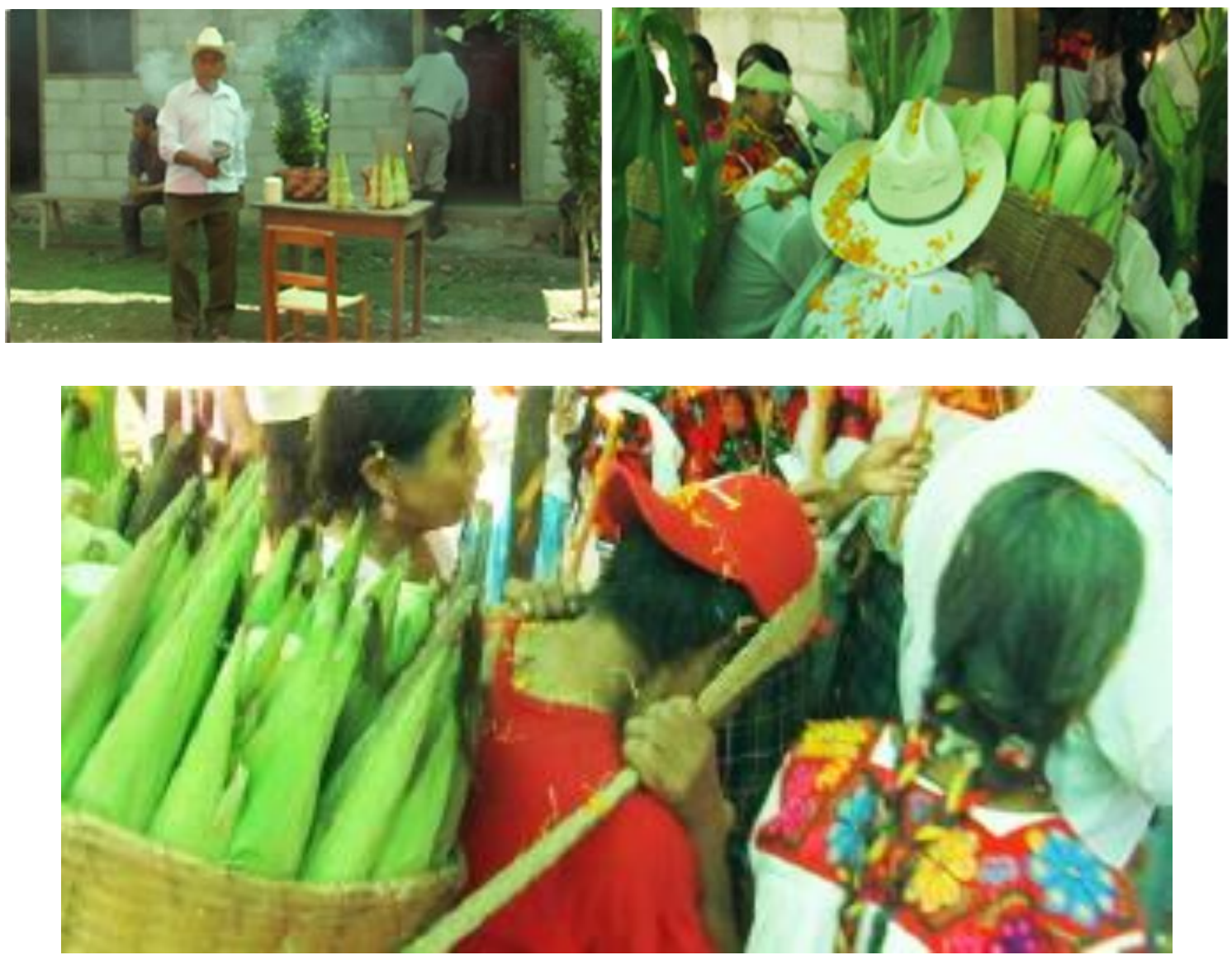

Iluminuras, Porto Alegre, v. 16, n. 40, p. 301-344, ago/dez, 2015. 

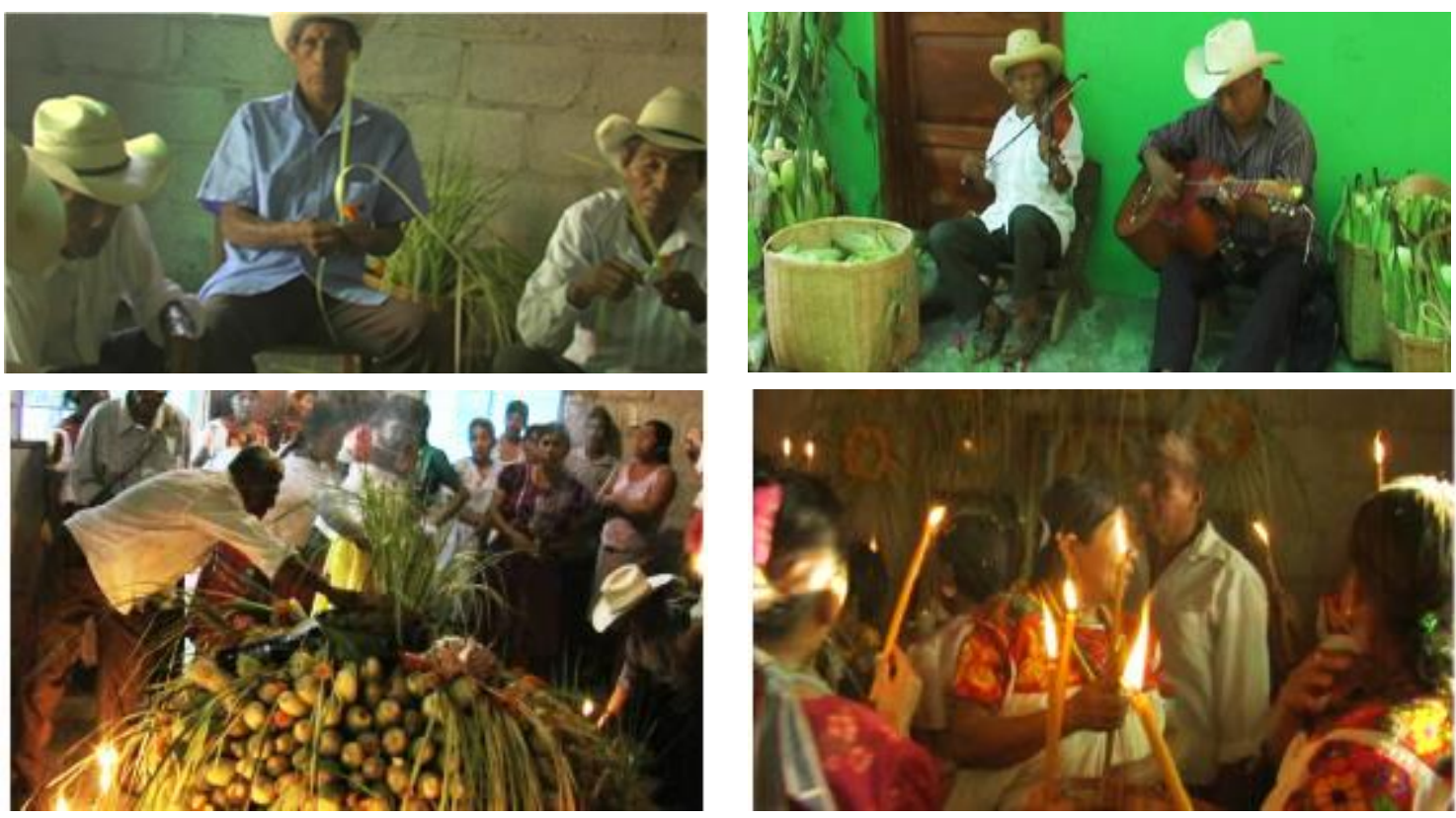

Imagens das filmagens que a aluna Eugênia realizou sobre o Ritual de colheita do Milho

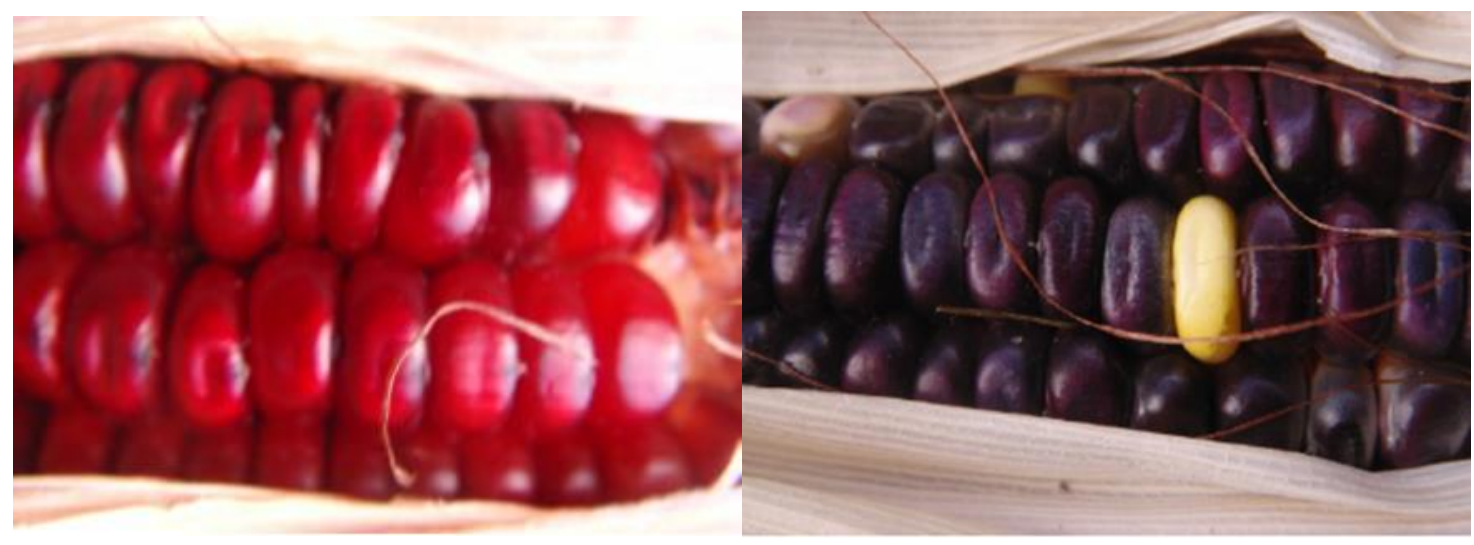

Espigas de milho que foram plantadas por mim no Brasil trazidas da Huasteca

A estadia na Sede da Huasteca realmente me havia ofertado momentos de profunda ritualidade e sacralidade. Em meio a nosso projeto sobre as celebrações da Festa de Xantolo, Dia dos Mortos, eu também havia vivido e encontrado outro rito tão importante para as culturas indígenas veracruzanas. 
A forma como eu vivia as nossas produções audiovisuais junto aos alunos permitiu-nos vivenciarmos todos estes rituais milenares. Alguns alunos tinham essas experiências mais demarcadas em suas vidas. No entanto, a grande maioria de nossos alunos também vivia aqueles ritos pela primeira vez. O que tornava nossa tarefa ainda mais importante. Não foram poucas vezes que pais e avós de alunos nos receberam com alegria por estarmos levando seus filhos a conhecerem por outro meio a sua própria cultura.

A sacralidade dos rituais vivenciados foram penetrando em minha alma. Acessar a vida dos antepassados de meus alunos, conhecer as formas rituais que traziam os mortos de meus alunos para as mesas das casas deles naqueles seguintes dias, foi me trazendo uma certa melancolia por juntar-me a meus familiares para ofertar eu também para os meus mortos. Eu não vinha me sentindo bem em acompanhar os meus alunos na casa deles e então para os cemitérios onde seus mortos estavam enterrados. Numa reunião com eles decidimos que quem se sentisse à vontade para realizar gravações com seus familiares e nos cemitérios de seus pueblos que poderiam levar as câmeras. Uma aluna e um aluno decidem levar.

Realmente Xantolo é uma celebração deveras importante para a cultura mexicana e cada aluno no final de nosso curso se destina a voltar para suas casas para estar com seus familiares, assim como eu, que decido ir para Malinaco, pequena cidade que fica a duas horas da Cidade do México, onde meu compadre Miguel Angel vivia com minha comadre andaluza Carmen $V_{i l c h e z}{ }^{26}$ e sua pequena filha Maya. Lá passamos todos juntos o Dia dos Mortos.

As demais informações relacionadas a este trabalho prefiro deixá-las para serem acessadas pela obra audiovisual.

${ }^{26}$ Carmen Vilchez: esposa de Miguel Angel Martinez. Assistente social e madrinha de minha filha. 


\section{Referências}

BATAILLE, Georges. El ojo pineal. Trad. Manuel Arranz. Valencia: Pre-textos, 1997.

DUSSEL, Enrique. 1492: o encobrimento do outro: a origem do mito da modernidade. Petrópolis: Ed. Vozes, 1993.

FOURNET-BETANCOUT, Raul. Questões de método para uma filosofia intercultural a partir da Ibero-América. São Leopoldo: Ed. UNISINOS, 1994.

JOHANSSON, Patrick: El sentido y los sentidos em la oralidad náhuatl prehispánica. Revista Acta poética, v. 26, n. 1, p. 515-546, 2005.

LENKENDORF, Carlos. Nosotros, otra realidad. Comunicação \& política, v. 7, n.2, 161-183, 2000.

LÉVI- STRAUSS, Claude. O Pensamento Selvagem. São Paulo: Papirus. 1969.

LIMA, Rodrigo Viana de. Interculturalidade latino-americana em Raúl Fornet-Betancourt. Revista de Estudos Culturais e da Contemporaneidade, n. 9, p. 101-133, 2014.

Recebido em: 23/10/2015.

Aprovado em: 26/12/2015. 